\title{
Direct Generation of Superhydrophobic Microstructures in Metals by UV Laser Sources in the Nanosecond Regime
}

\author{
J.L. Ocaña, R. Jagdheesh, M. Díaz, J.A. Porro,
} F. Cordovilla, I. Angulo, D. Huerta, J.T. Cardoso

UPM Laser Centre. Universidad Politécnica de Madrid

Campus Sur UPM. Edificio La Arboleda.

Ctra. de Valencia, km. 7,300. 28031 Madrid. SPAIN

Tel.: (+34) 913363099 . Fax: (+34) 913363000.

email: jlocana@etsii.upm.es

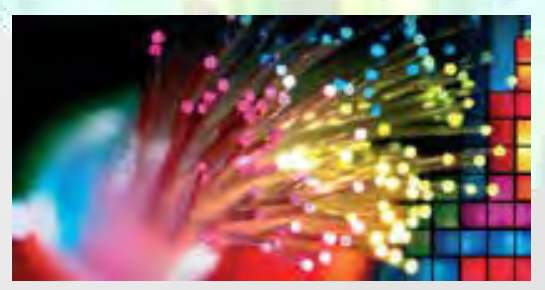

10" INTERNATIONAL LASER SYMPOSIUM

\& INTERNATIONAL SYMPOSIUM

"TAILORED JOINING «
February 27-28, 2018

International Congress Center Dresden

Germany 


\section{Generation of Modified Wettability Metallic Surfaces by Short Pulse Lasers}

\section{OUTLI NE:}

1. Introduction: The Search for Hydrophobic Surfaces

2. Basic Experimental Setup and I nitial Results: Hydrophobicity I nduced by Surface Patterning with I ndividual ns Laser Pulses

3. The Next Step: Extended Surfaces Patterning with ns Laser Generated Channels.
a) Effect of repetition rate / processing speed
b) Effect of hatch distance

4. Generation of Withstanding Superhydrophobic Surfaces with 2DMicropillar Patterns

5. The Way for the Generation of Low Wettability and Bio-inspired Self-Cleaning Surfaces

6. Conclusions 


\section{INTRODUCTION.}

\section{B The search for Hydrophobicity (1/3):}

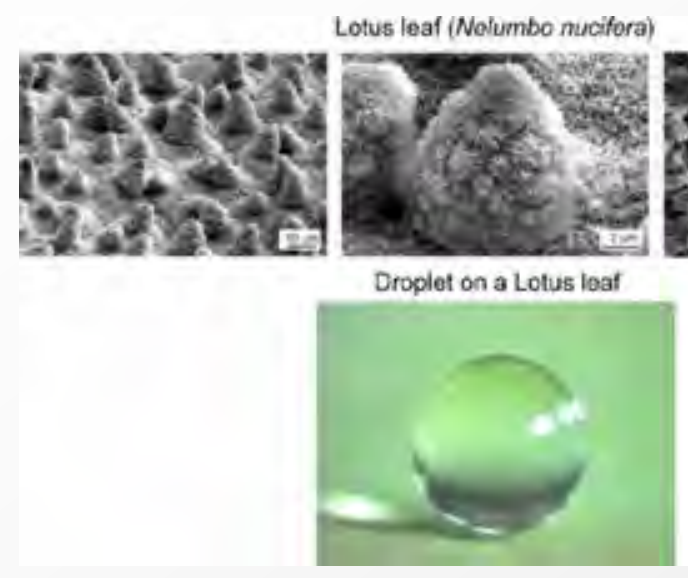

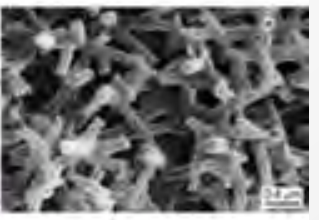
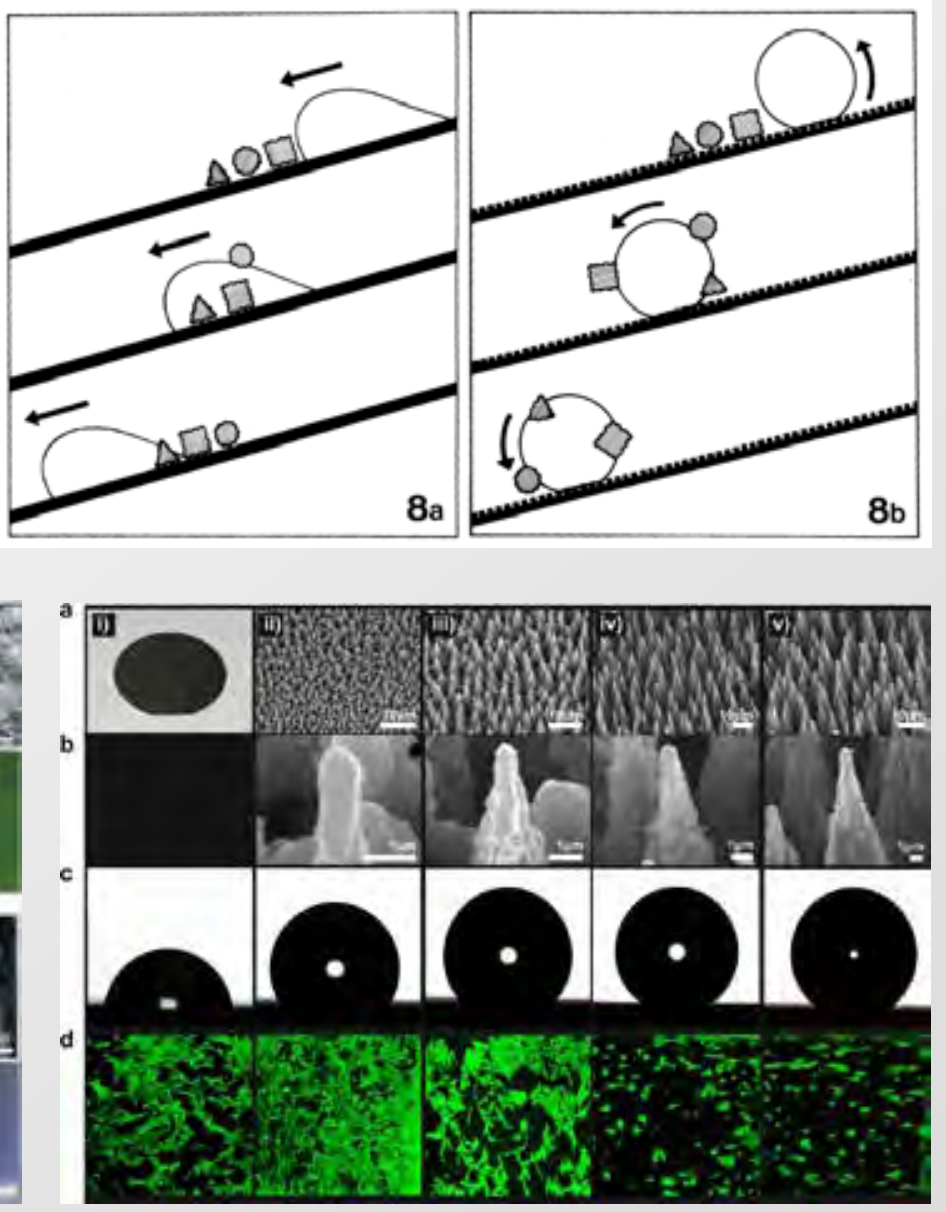

A. RANELLA et al.: Acta Biomaterialia, $\underline{6}, 2711-2720$ (2010)

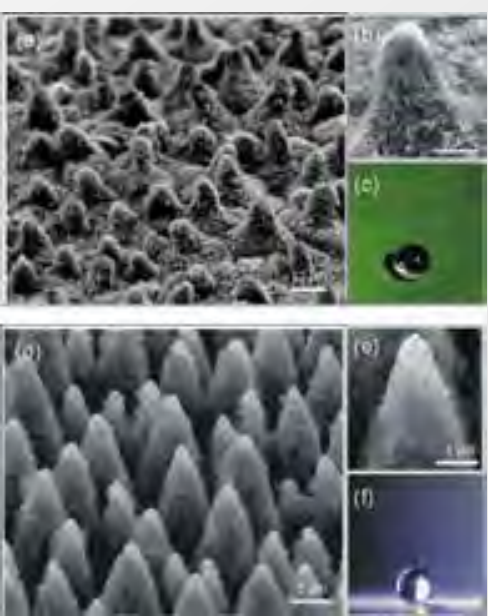

10 INTERNATIONAL LASER SYMPOSIUM $\&$ INTERNATIONAL SYMPOSIUM "TAILORED JOINING.
February 27-28, 2010 international Congress Center Dieuden Germany 


\section{INTRODUCTION (Cont.)}

\section{B The search for Hydrophobicity (2/3):}
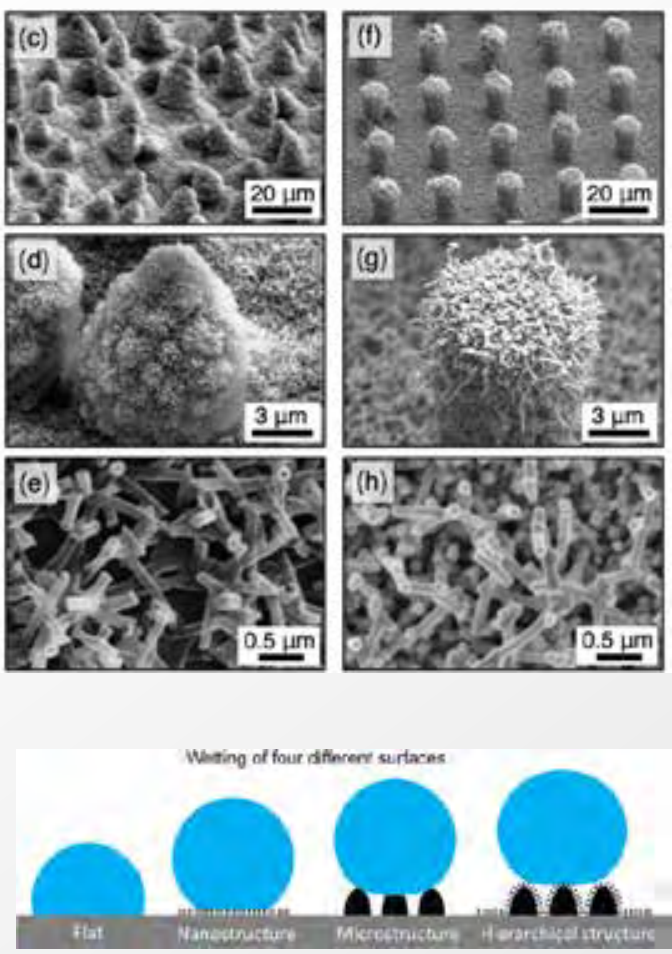

(a) Flat surface

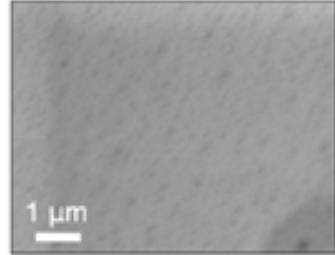

(b) Microstructured $(\mathrm{S}=0.13)$

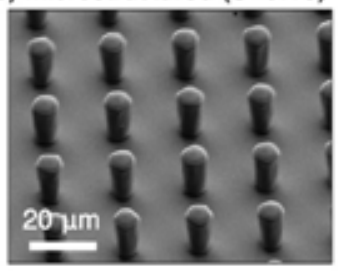

(c) Microstructured $(\mathrm{S}=0.38)$

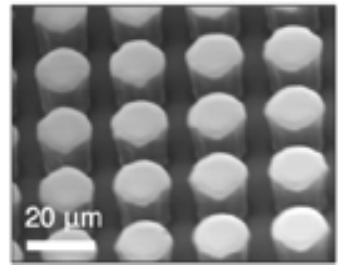

(d) Nanostructured $\left(\mathrm{S}_{\mathrm{eff}}=0.03\right)$

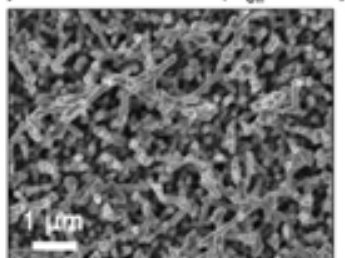

(e) Hierarchical $(S=0.13)$

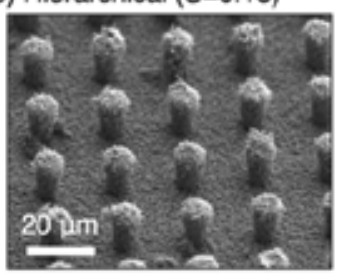

(f) Hierarchical $(\mathrm{S}=0.38)$

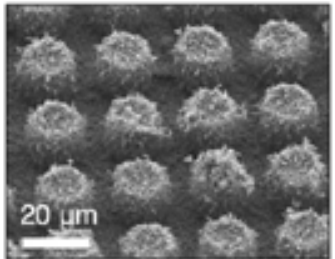

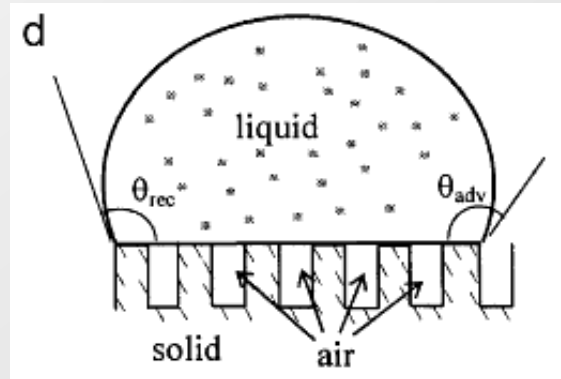

$\mathrm{S}=\pi d^{2} / 4 L^{2}$

$\square$ Equilibrium contact angle $\square$ Contact angle hysteresis

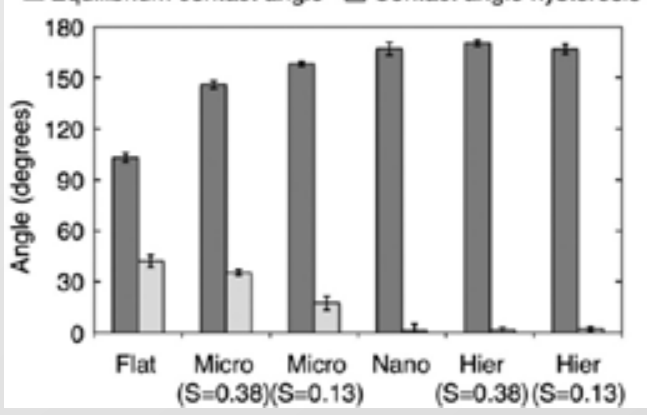

M. MCCARTHY et al.: Appl. Phys. Lett., 100, 263701 (2012) 


\section{INTRODUCTION (Cont.)}

\section{B The search for Hydrophobicity (3/3):}

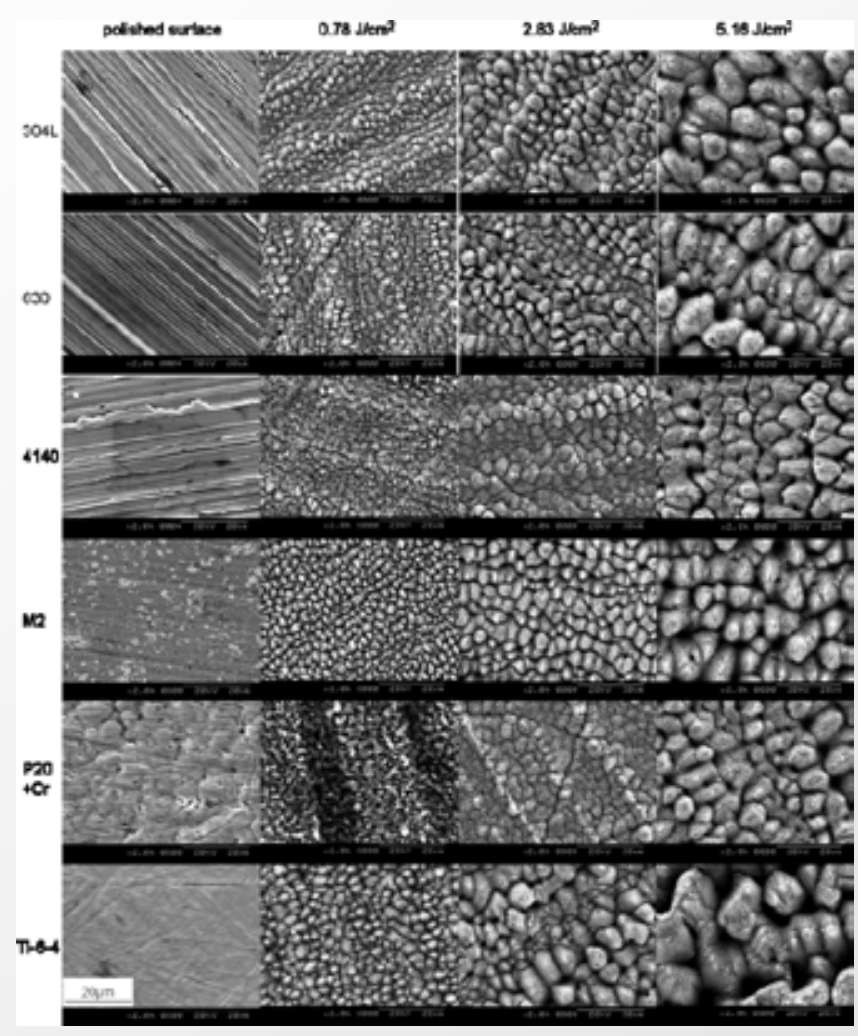

A.M. KIETZIG et al.: Langmuir, 25, 4821-4827 (2009)

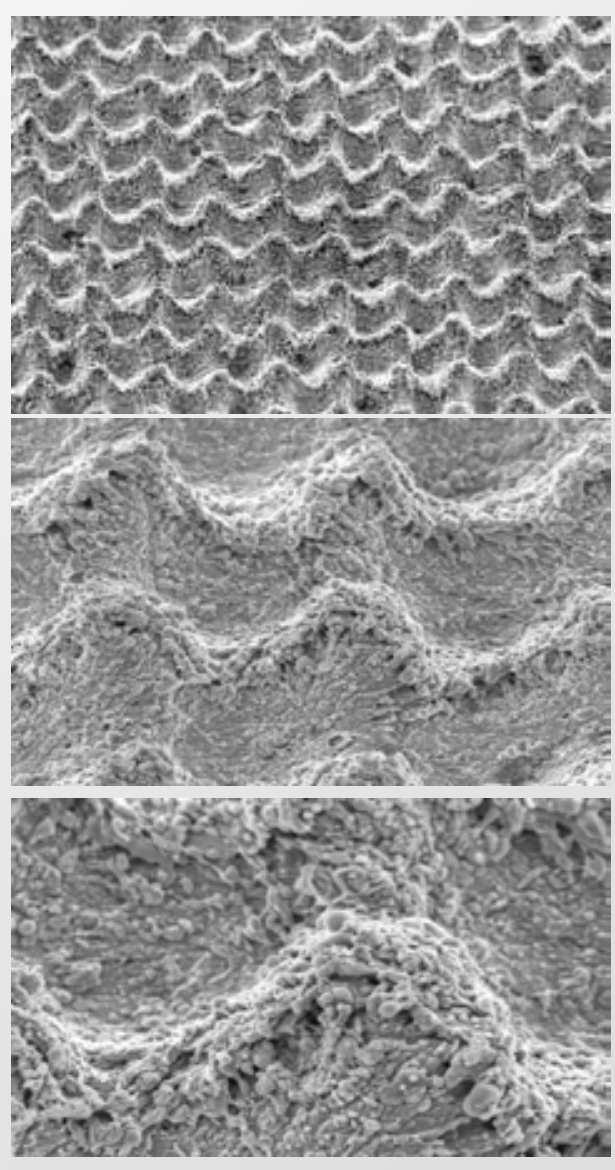

M. TANG et al..: J. Laser Micro/Nanoeng., 6, 1-9 (2011)
CENTRO LÁSER

UNIVERSIDAD POLITÉCNICA DE MADRID

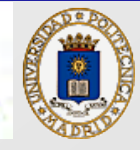

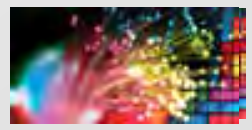

10. INTERNATIONAL LASER SYMPOSIUM \& INTERNATIONAL SYMPOSIUM "TAILORED HOINING* february 27-28, 2010 International Congress Center Diesten Germany 


\section{EXPERIMENTAL SETUP (BASIC): THE IRRADIATION SYSTEM}

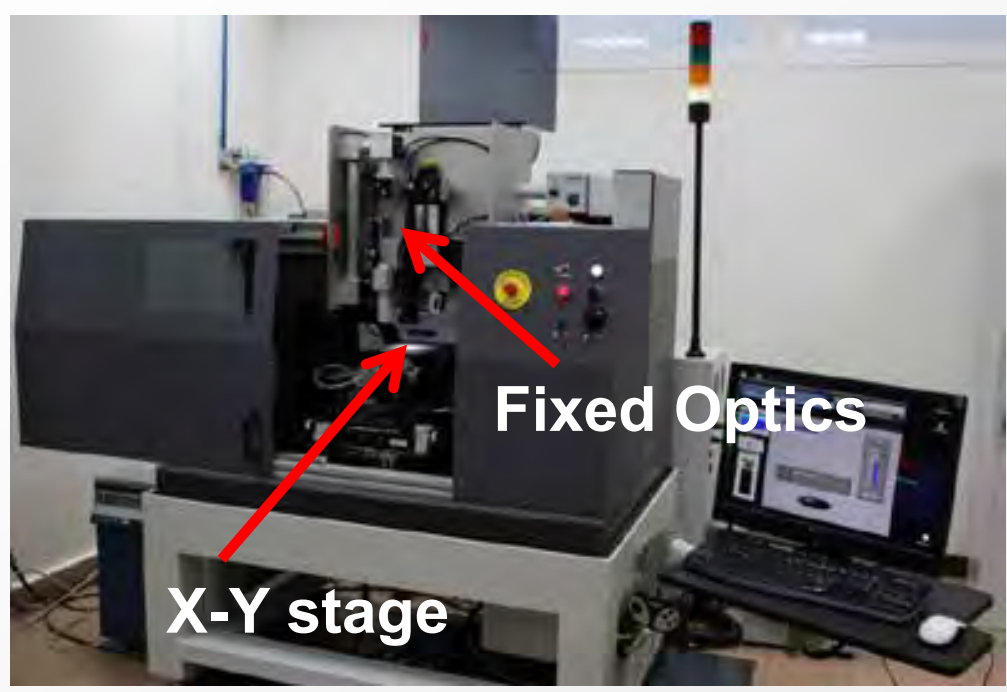

Substrate

: Al

Thickness

: $>50 \mu \mathrm{m}$

Wavelength

: $355 \mathrm{~nm}$

Laser Average Power

: $500 \mathrm{~mW}$

Pulse duration

: $30 \mathrm{~ns}$

Energy/pulse

: $\sim 2.50 \mu \mathrm{J}$

Spot Diameter

: $10-20 \mu \mathrm{m}$

Fluence (Single pulse)

: $0.81-3.25 \mathrm{~J} / \mathrm{cm}^{2}$

Hatch distance

: 10-50 $\mu \mathrm{m}$

Pulse Rep. Rate

: 25-250 kHz

\section{UV Radiation allows smaller spot size!}

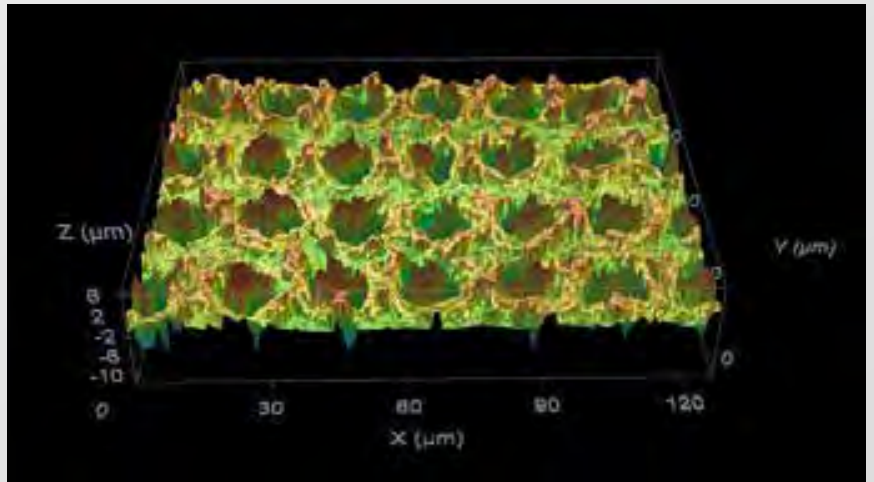




\section{INITIAL RESULTS}
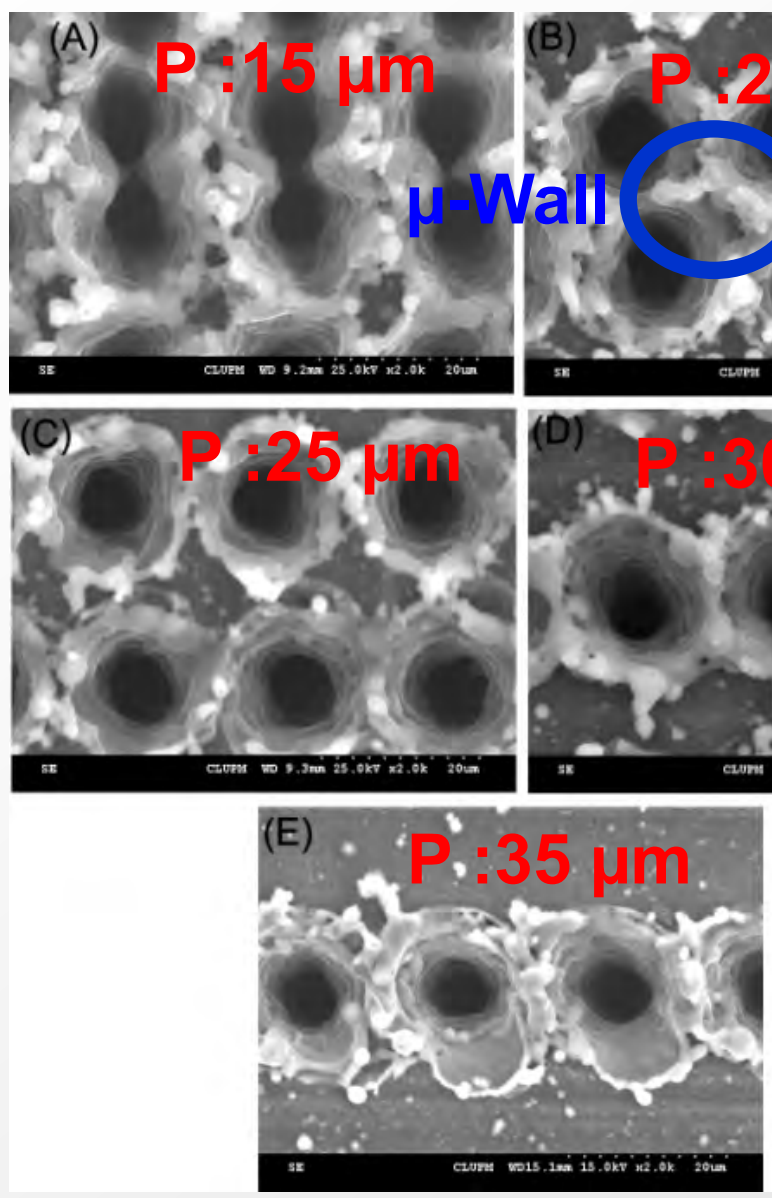

Morphology / Microstructure
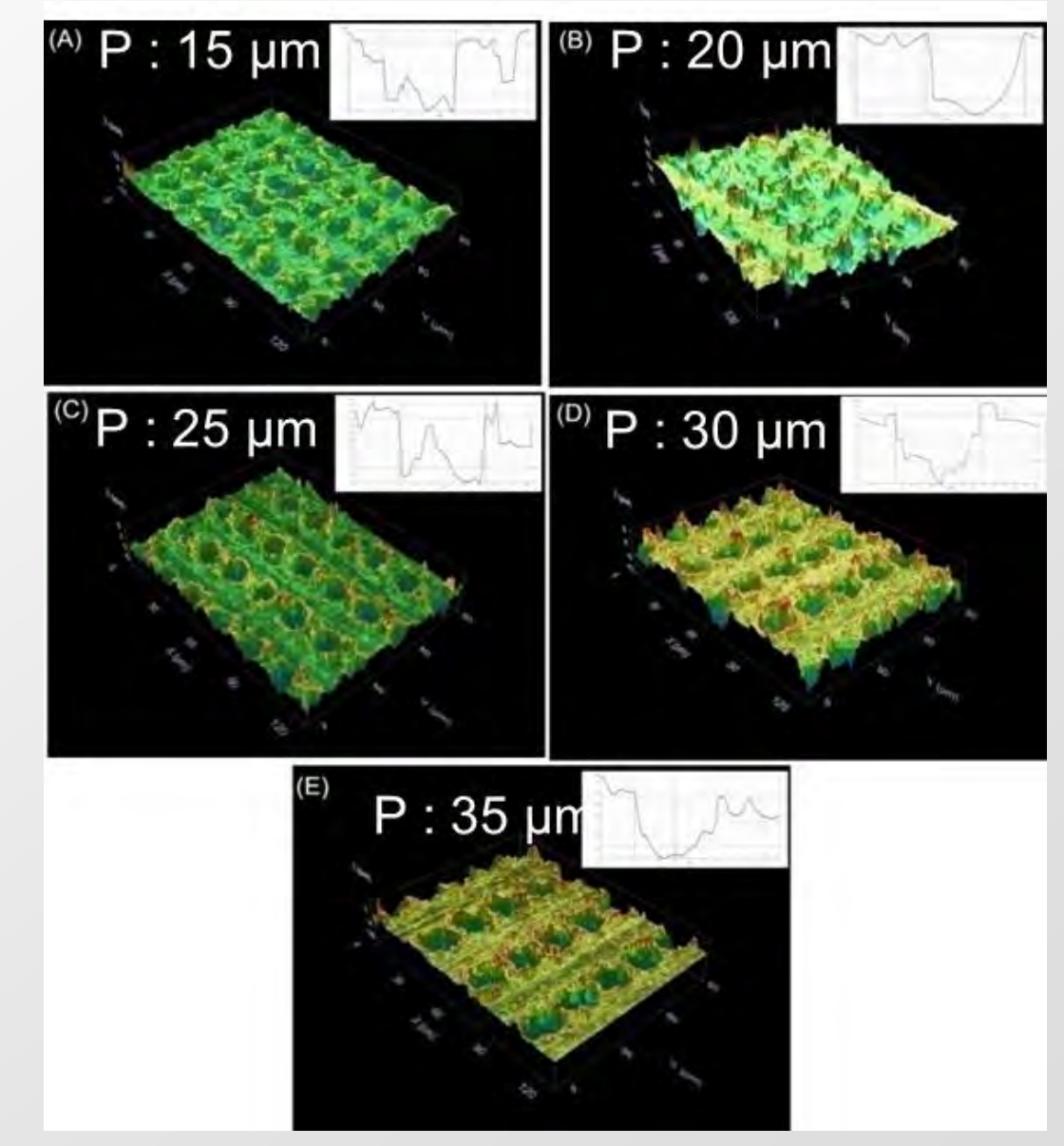

\section{CENTRO LÁSER} UNIVERSIDAD POLITÉCNICA DE MADRID
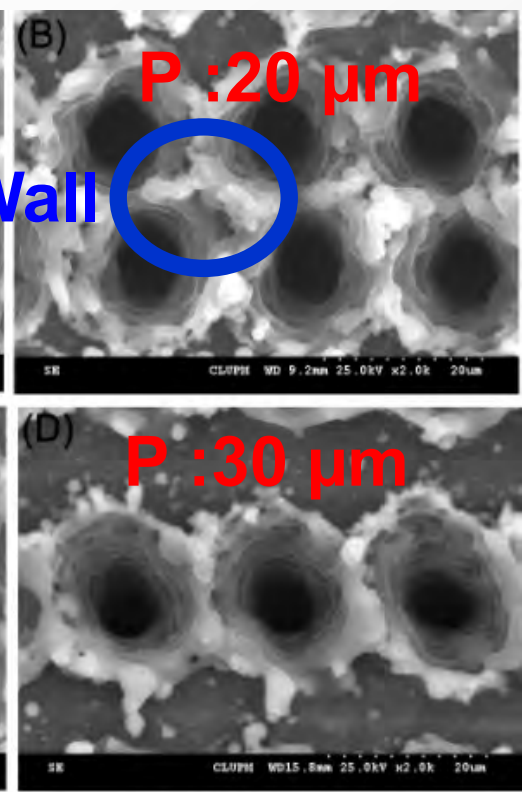

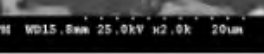

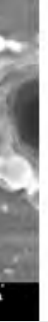




\section{INITIAL RESULTS}

\section{Morphology / Microstructure}

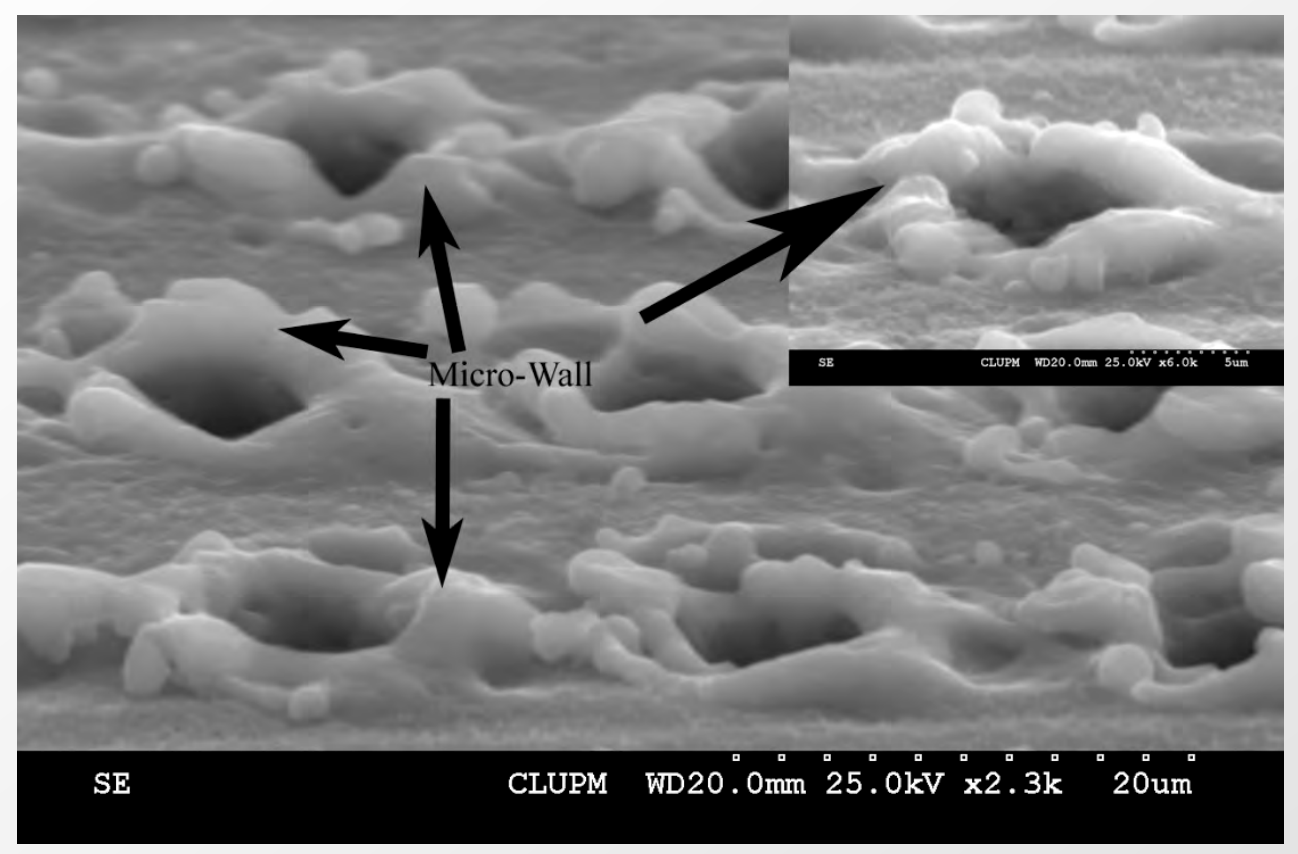

- For a given range of processing conditions, a microwall is formed above the metal surface. This contributes to coexistence of different length scales (hierarchical microstructure) and the creation of an extra-structure allowing additional trapping of air, thus improving the composite interface between the surface and the liquid which motivates hydrophobicity.

- This complex structured can be appropriately controlled in order to provide a range of surface wettability (Contact Angle, CA) properties. 

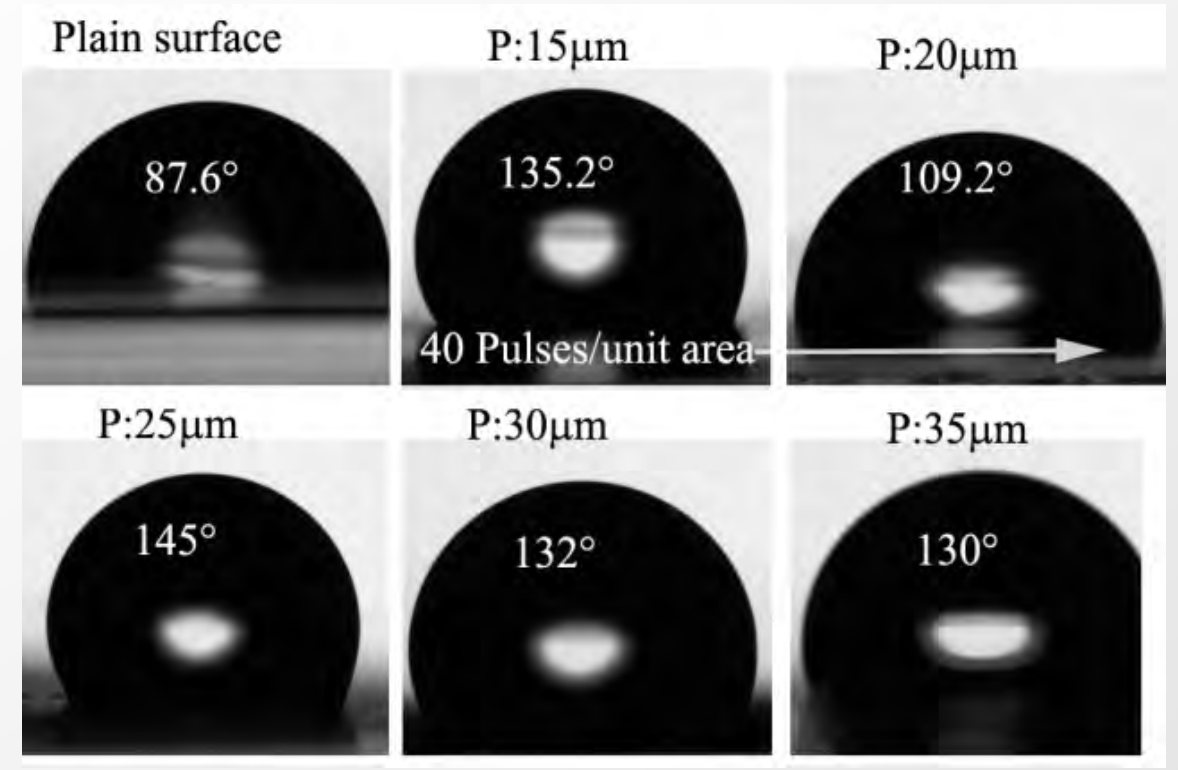

- The SCA measurements were performed with 8-12 $\mu \mathrm{L}$ water droplets, showing a high degree of repeatability.

- A clear hydrophobic effect $\left(90^{\circ} \leq \mathrm{SCA} \leq 150^{\circ}\right)$ was introduced by the generated microstructure

- For the particular case envisaged, an optimum value of SCA was obtained around $P=25 \mu \mathrm{m}$, reaching a maximum contact angle around $145^{\circ}$.

- The result was attributed to the variability of the degree of hierarchical microstructure generated under each parametric choice. 


\section{NEXT STEP: CHECK FOR REPRODUCIBILITY ON EXTENDED SURFACES}

Generation of near-Superhydrophobic surfaces with 1D-microchannels
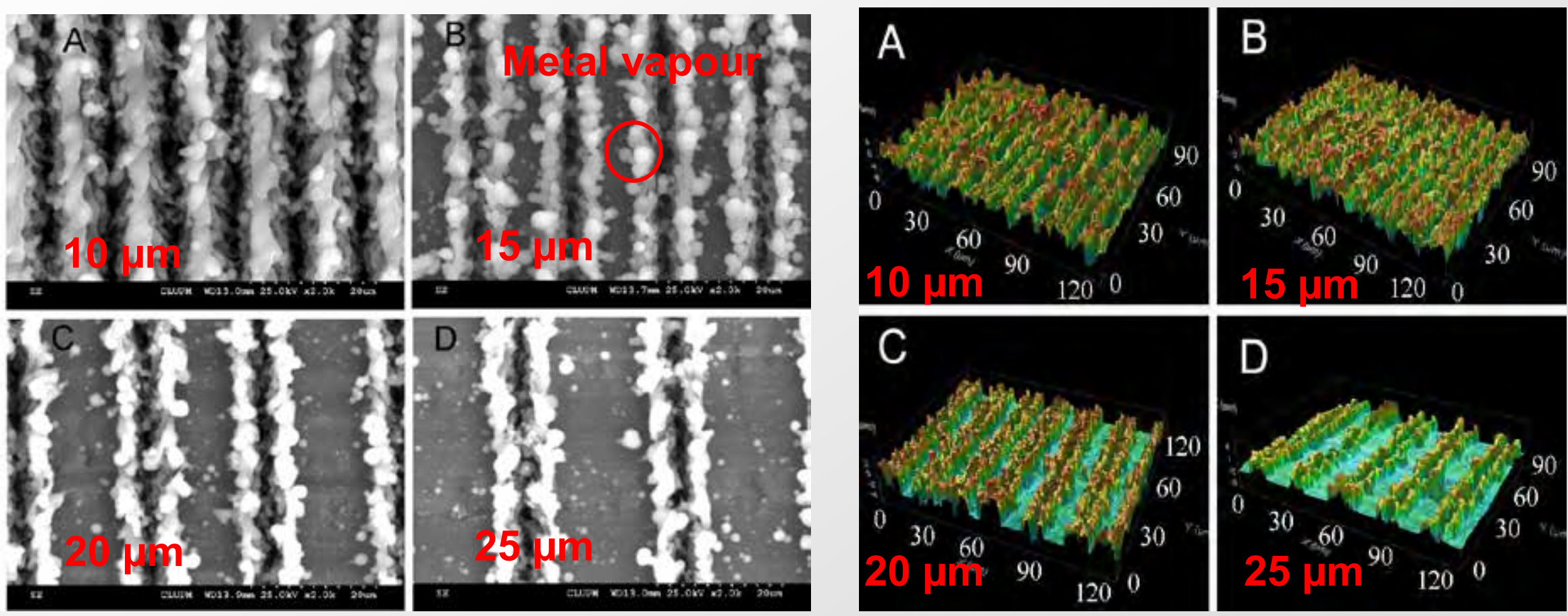


\section{EXPERIMENTAL SETUP (I)}

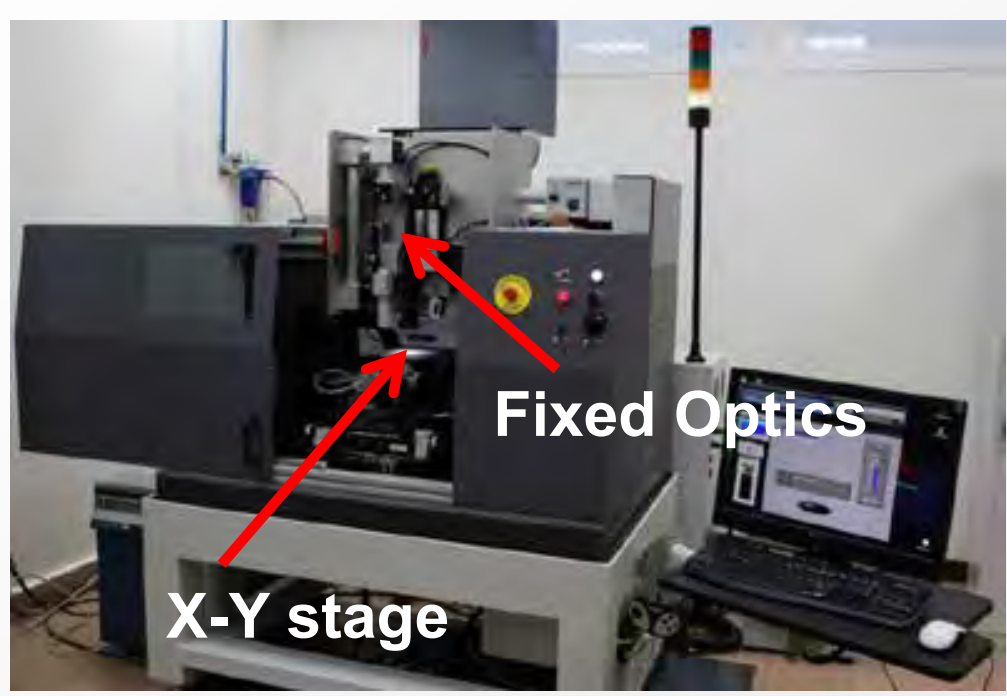

UV Radiation allows smaller spot size!
Study on the effect of Rep. Rate

$\begin{array}{ll}\text { Substrate } & : \text { Al, SS, Si } \\ \text { Thickness } & : 100 \mu \mathrm{m} \\ \text { Wavelength } & : 355 \mathrm{~nm} \\ \text { Laser Average Power } & : 500 \mathrm{~mW} \\ \text { Pulse duration } & : 30 \mathrm{~ns} \\ \text { Energy/pulse } & : 2.56 \mu \mathrm{J} \\ \text { Spot Diameter } & : 10 \mu \mathrm{m} \\ \text { Fluence (Single pulse) } & : 3.25 \mathrm{~J} / \mathrm{cm}^{2} \\ \text { Hatch distance } & : 20 \mu \mathrm{m} \\ \text { Pulse Rep. Rate } & : 25-250 \mathrm{kHz}\end{array}$

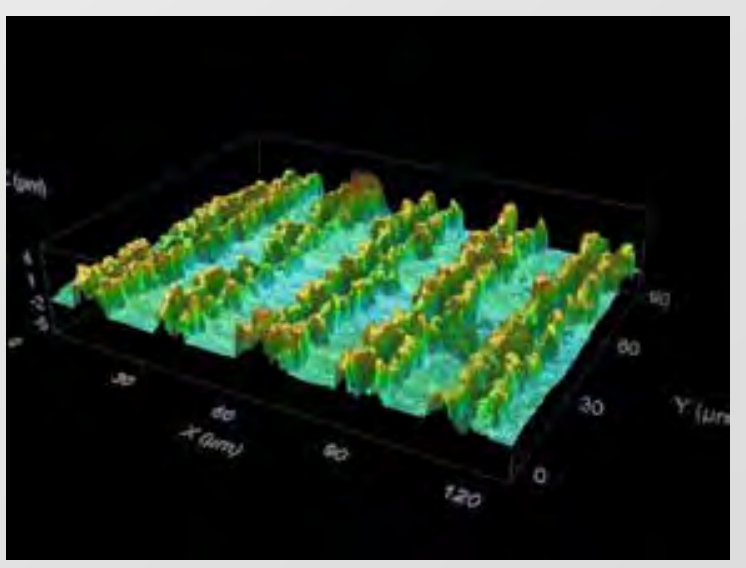




\section{RESULTS (I)}

Morphology / Microstructure

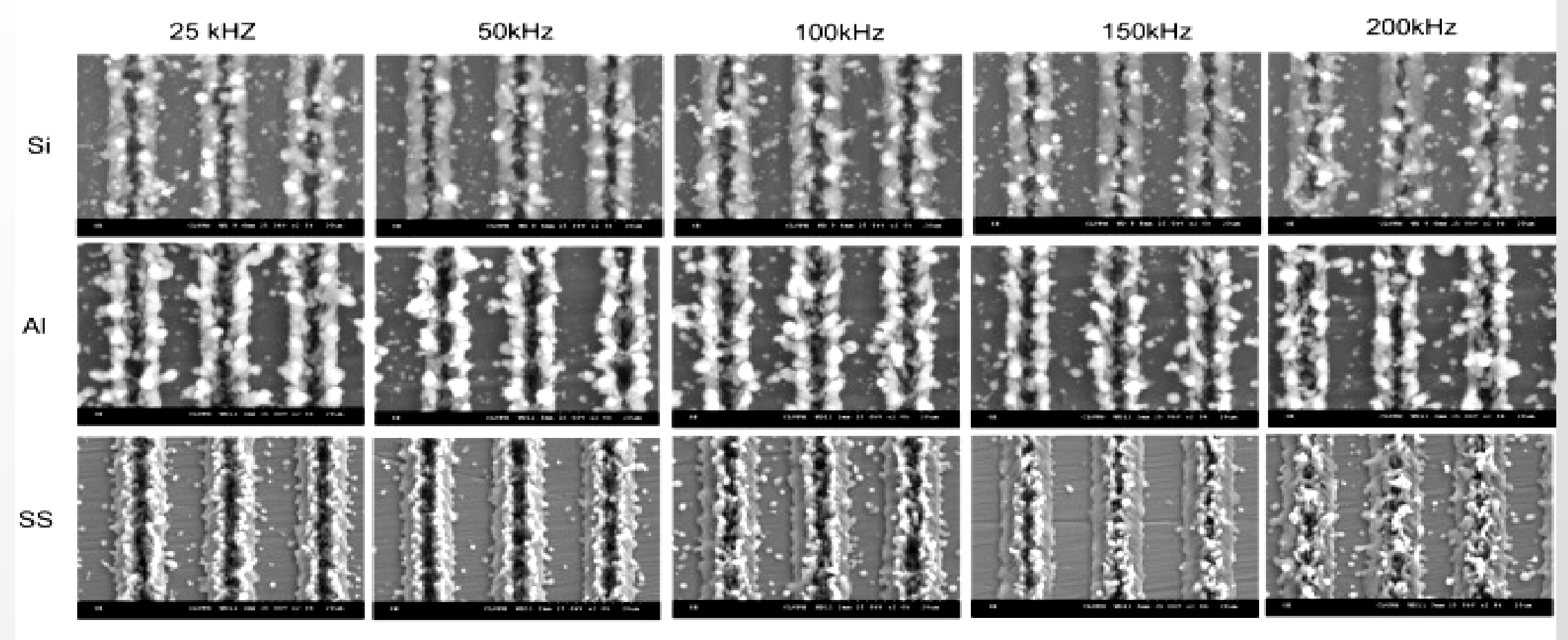

* CENTRO LÁSER

UNIVERSIDAD POLITÉCNICA DE MADRID
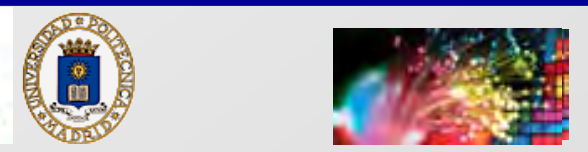

10. INTERNATIONAL LASER SYMPOSIUM \& INTERNATIONAL SYMPOSIUM "TAILORED JOINING. 

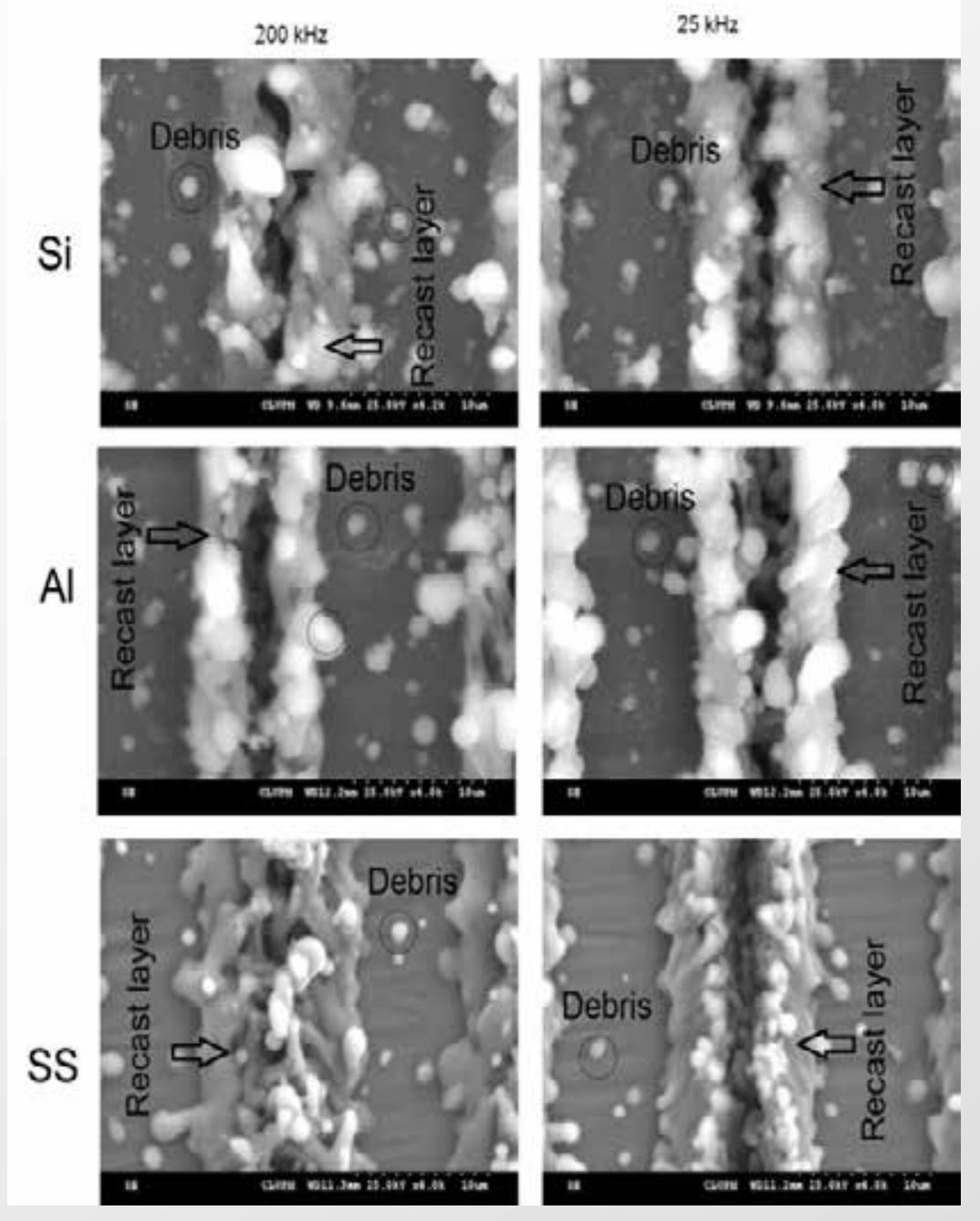
$200 \mathrm{kHz}$
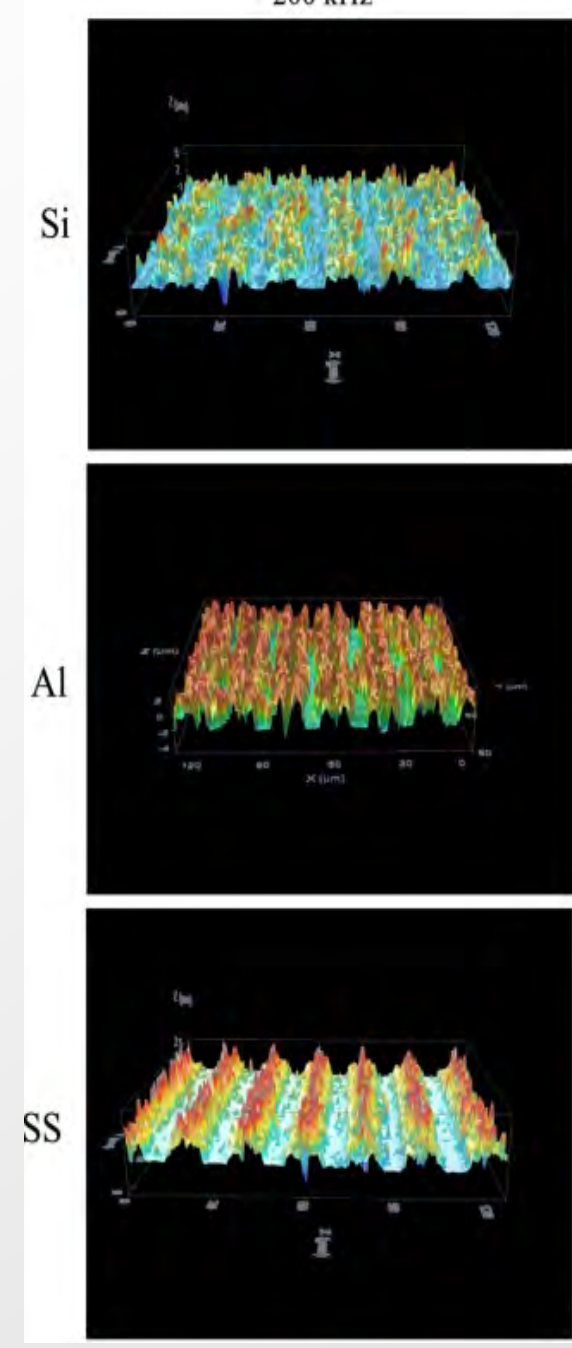

$25 \mathrm{kHz}$
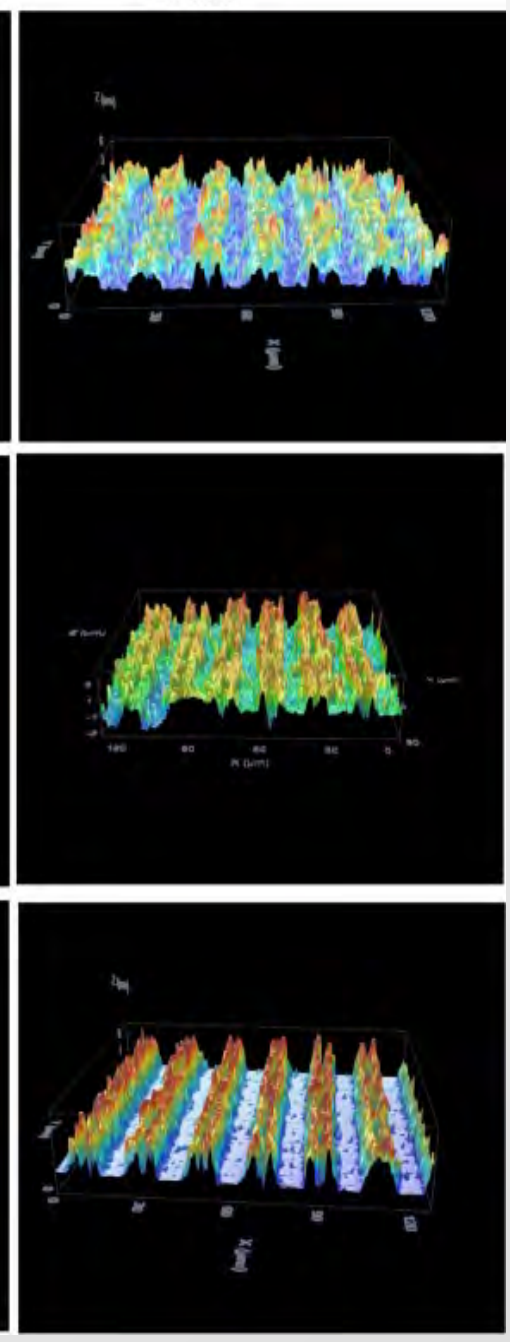


\section{RESULTS (I)}

Analysis of Channel depth vs. Rep. Rate

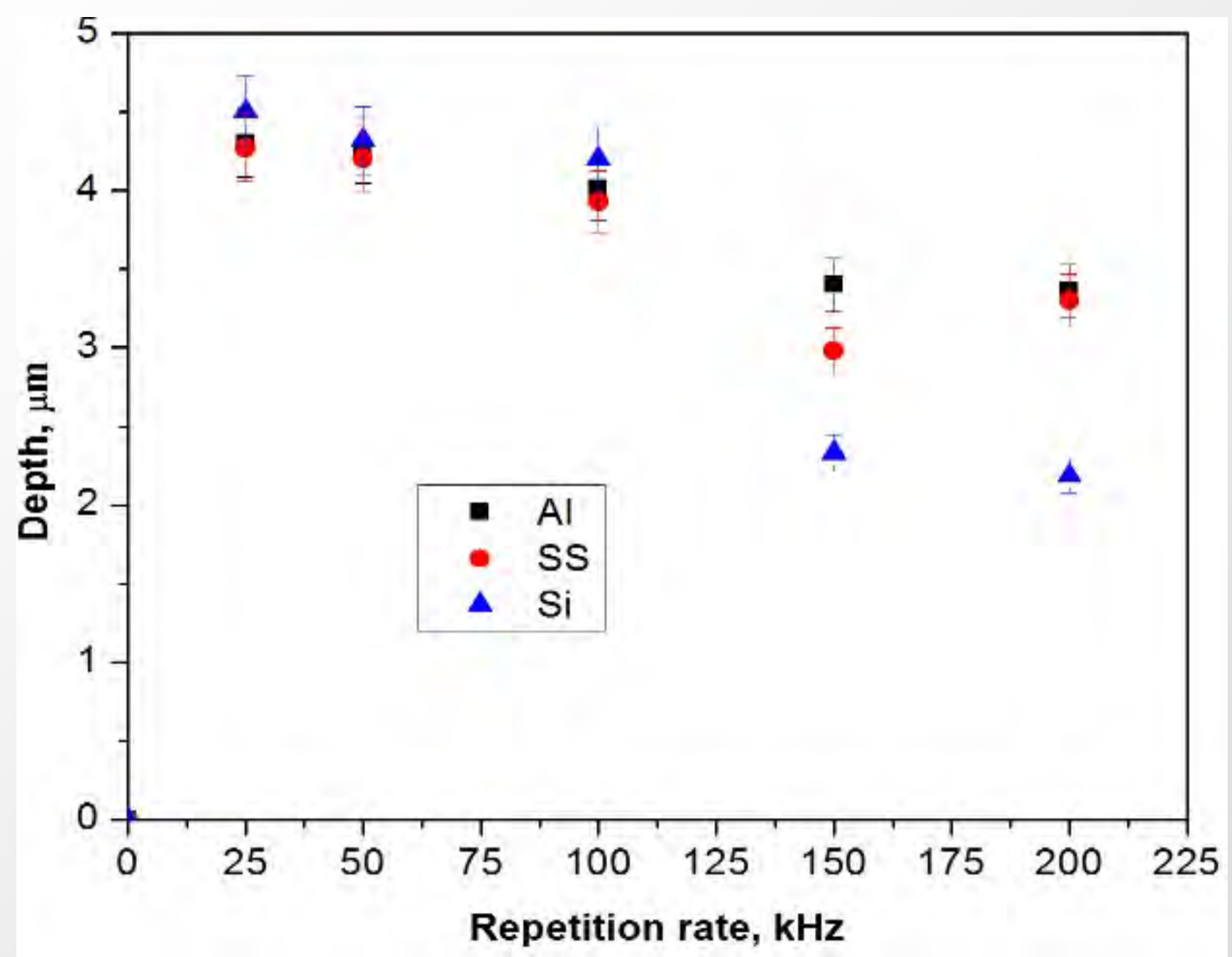




\section{EXPERIMENTAL SETUP (II)}

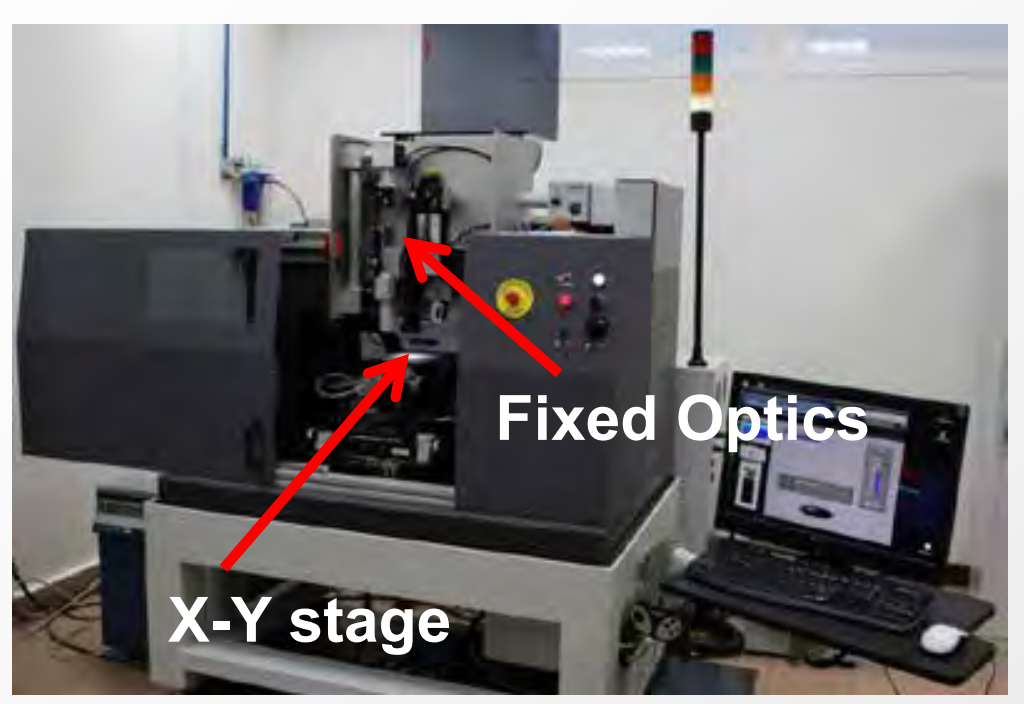

UV Radiation allows smaller spot size!
Study on the effect of Hatch distance

$\begin{array}{ll}\text { Substrate } & : \text { Al } \\ \text { Thickness } & : 100 \mu \mathrm{m} \\ \text { Wavelength } & : 355 \mathrm{~nm} \\ \text { Laser Average Power } & : 500 \mathrm{~mW} \\ \text { Pulse duration } & : 30 \mathrm{~ns} \\ \text { Energy/pulse } & : 2.56 \mu \mathrm{J} \\ \text { Spot Diameter } & : 15 \mu \mathrm{m} \\ \text { Fluence (Single pulse) } & : 2,83 \mathrm{~J} / \mathrm{cm}^{2} \\ \text { Pulse Rep. Rate } & : 100 \mathrm{kHz} \\ \text { Hatch distance } & : 10-25 \mu \mathrm{m}\end{array}$

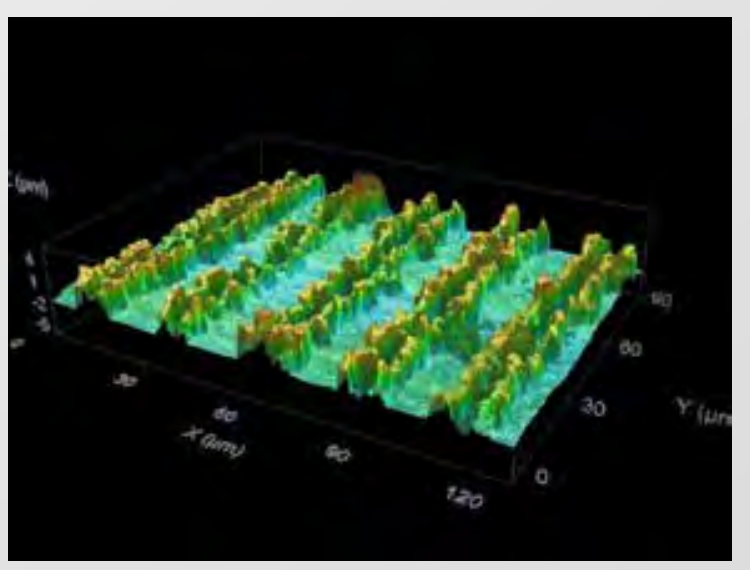



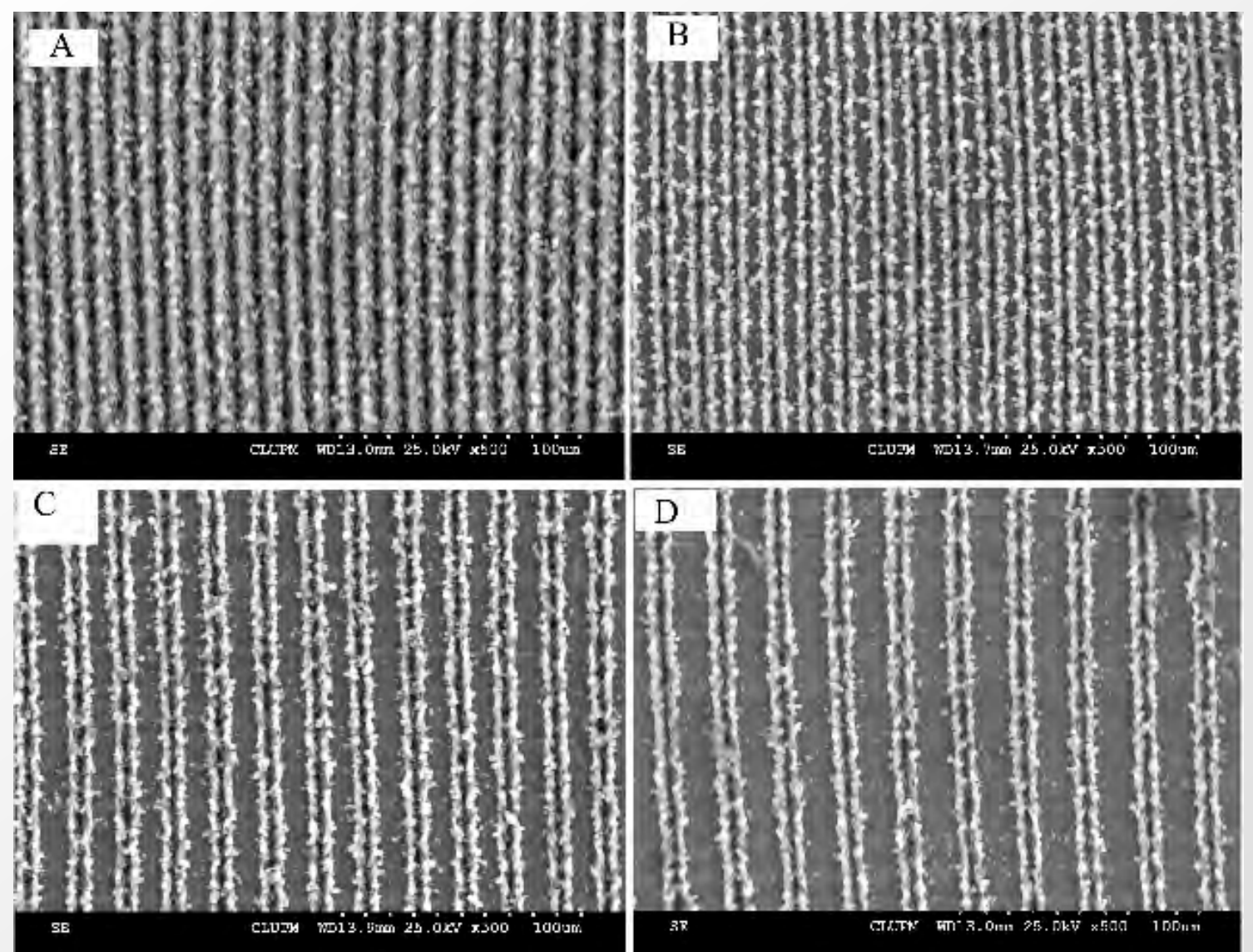

$$
\begin{aligned}
& \varnothing=15 \mu \mathrm{m} \\
& F=2,83 \mathrm{~J} / \mathrm{cm}^{2} \\
& f=100 \mathrm{kHz} \\
& d=10-25 \mu \mathrm{m}
\end{aligned}
$$

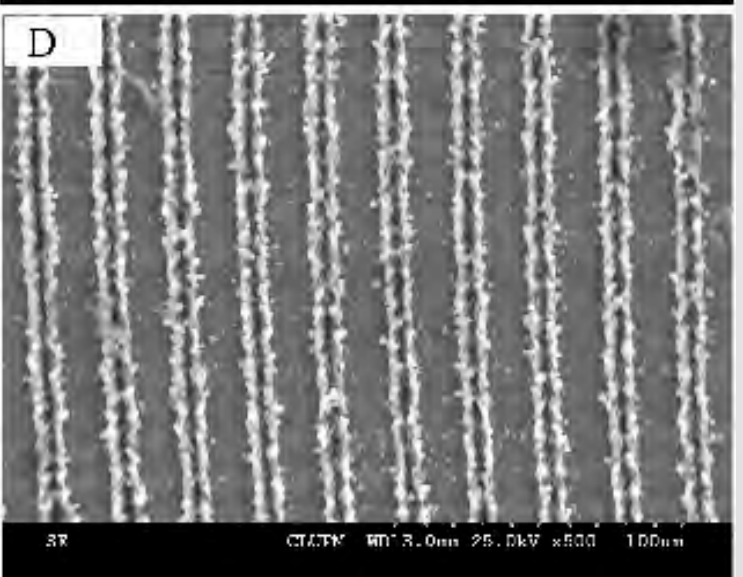

$$
\begin{aligned}
& \text { A: } d=10 \mu \mathrm{m} \\
& B: d=15 \mu \mathrm{m} \\
& C: d=20 \mu \mathrm{m} \\
& D: d=25 \mu \mathrm{m}
\end{aligned}
$$




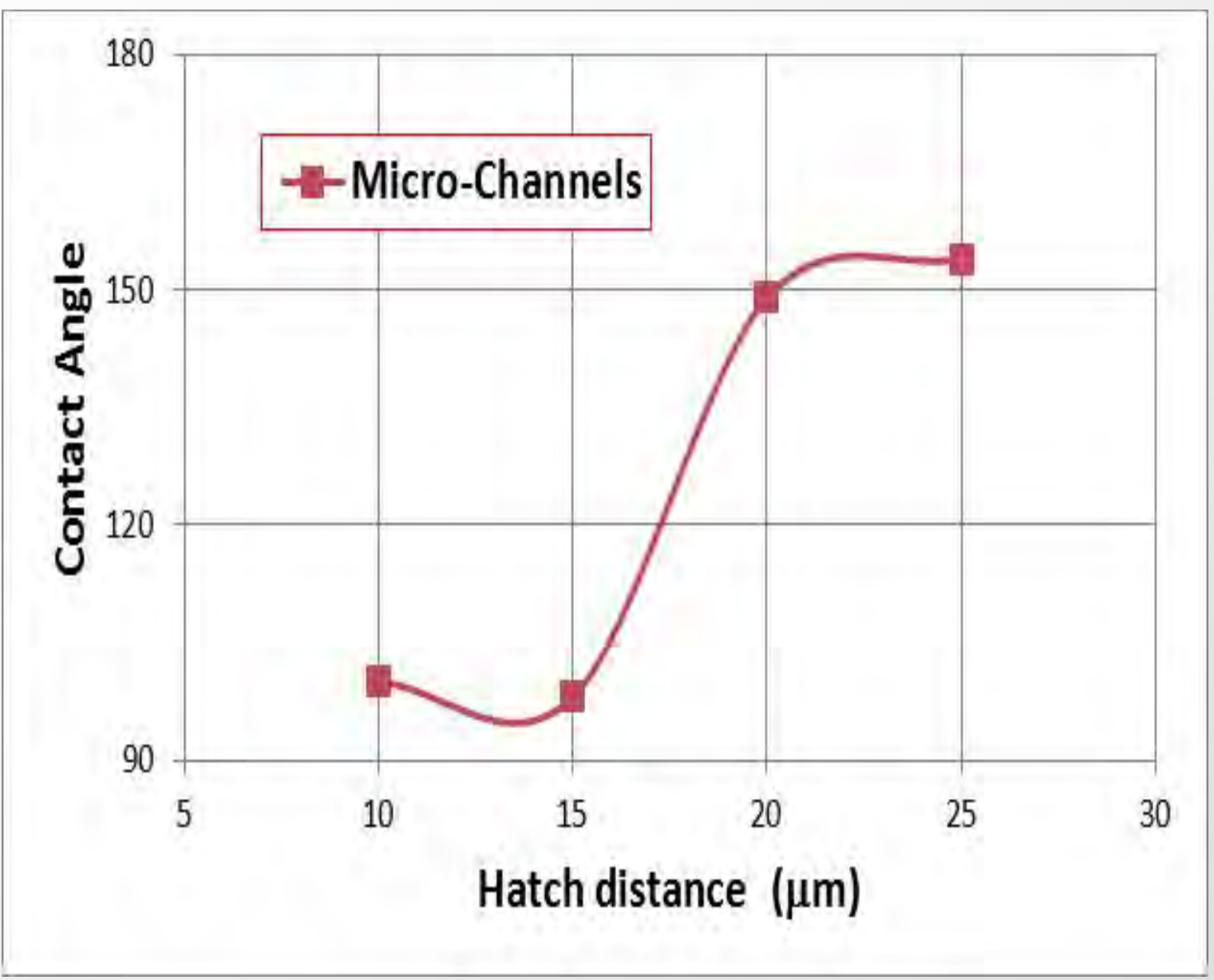




\section{PARTIAL CONCLUSIONS}

- High degree of hydrophobicity (near-superhydrophobicity) on different materials (Silicon, pure aluminum and AISI 304 Stainless Steel) plates has been achieved in a single processing step by means of ns lasers working at UV wavelengths and with final applied energies in the range of $100-150 \mathrm{~J} / \mathrm{cm}^{2}$ and instant energy densities in the range of $10^{8}-10^{9} \mathrm{~W} / \mathrm{cm}^{2}$. Better, stable superhydrophobic properties can be achieved by means of 1D-microchannel patterning.

- The desired hydrophobicity has been achieved by means of the generation of complex microstructures consisting of mixed micro-nano channels and interspacing walls resulting from laser ablation and melting/recast approaching near-hierarchical surface structure patterns.

- The obtained degree of hydrophobicity has been observed to critically depend in a first term on the pulse overlapping pitch applied to the surface. Optimum values of contact angle (SCA) close to superhydrophobicity have been achieved with particular choices of pulse overlapping pitches achievable by means of the high accuracy provided by the used lasers (working in the UV) .

- The key parameter of final micro-channel depth has been analyzed for different processing speeds/repetition rates, a clear deleterious effect having being observed for processing speeds beyond a critical value (around $100 \mathrm{kHz}$ repetition rate $/ 25-40 \mathrm{~mm} / \mathrm{s}$ linear process speed) for the three kinds of materials analyzed).

- Additionally, the obtained degree of hydrophobicity has been observed to depend critically on the hatch distance (distance between successive parallel 1D tracks), the existence of a threshold value drastically changing the wettability character of the treated surface having been found. 


\section{THE DEFINITIVE APPROACH: THE GENERATION OF $\mu$-CELL PATTERNING}

Generation of Withstanding Superhydrophobic Surfaces with 2D-Micropillar Patterns
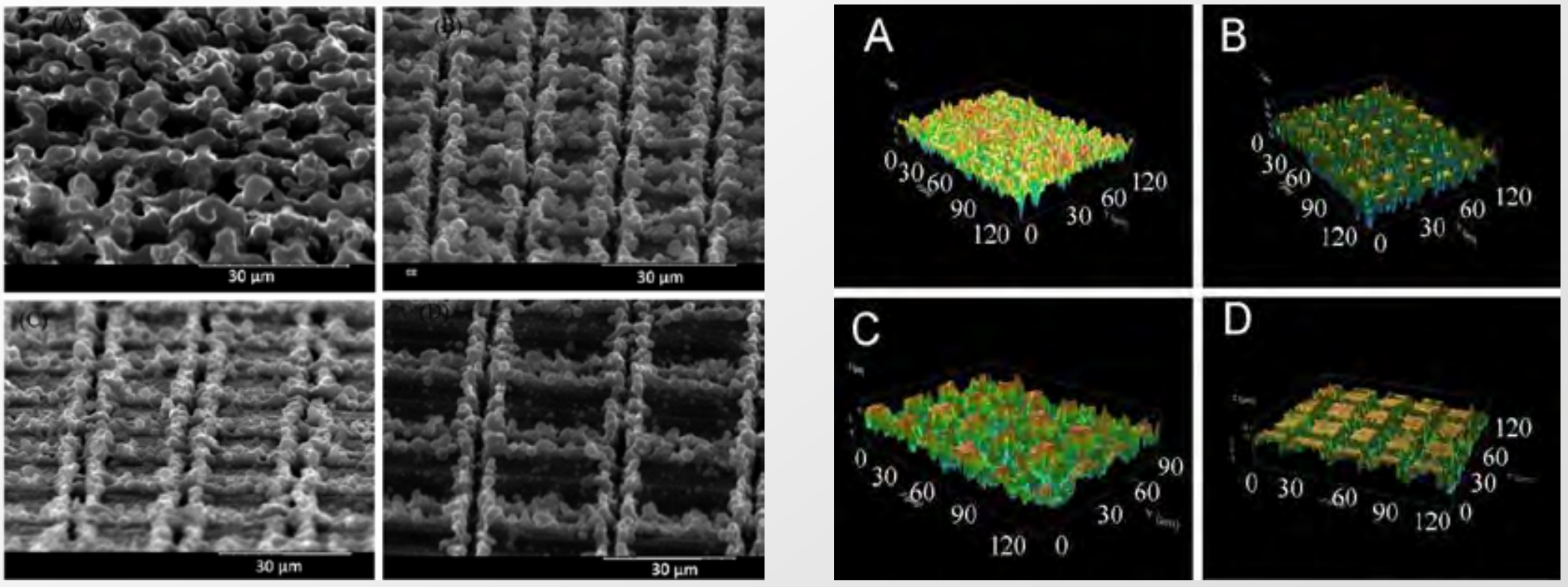


\section{EXPERIMENTAL SETUP (III)}

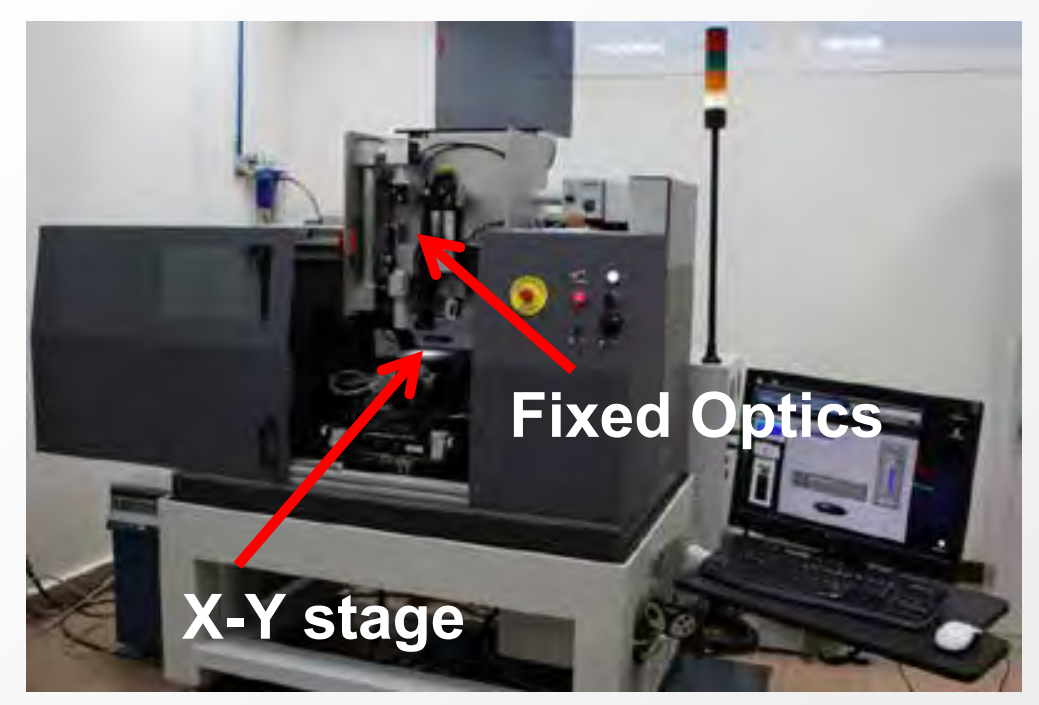

UV Radiation allows smaller spot size !
Study on the effect of Hatch distance

$\begin{array}{ll}\text { Substrate } & : \text { Al } \\ \text { Thickness } & : 100 \mu \mathrm{m} \\ \text { Wavelength } & : 355 \mathrm{~nm} \\ \text { Laser Average Power } & : 500 \mathrm{~mW} \\ \text { Pulse duration } & : 30 \mathrm{~ns} \\ \text { Energy/pulse } & : 2.56 \mu \mathrm{J} \\ \text { Spot Diameter } & : 15 \mu \mathrm{m} \\ \text { Fluence (Single pulse) } & : 2,83 \mathrm{~J} / \mathrm{cm}^{2} \\ \text { Pulse Rep. Rate } & : 100 \mathrm{kHz} \\ \text { Hatch distance } & : 10-25 \mu \mathrm{m}\end{array}$

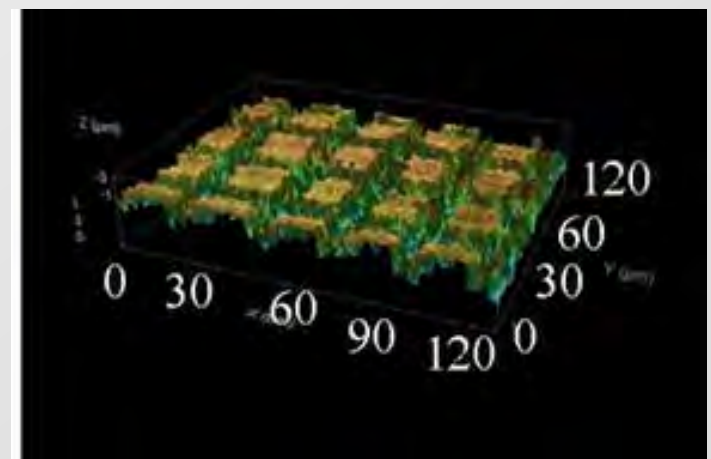




\section{RESULTS (III)}

Comparison of CA for $\mu$-Channels and $\mu$-Pillars

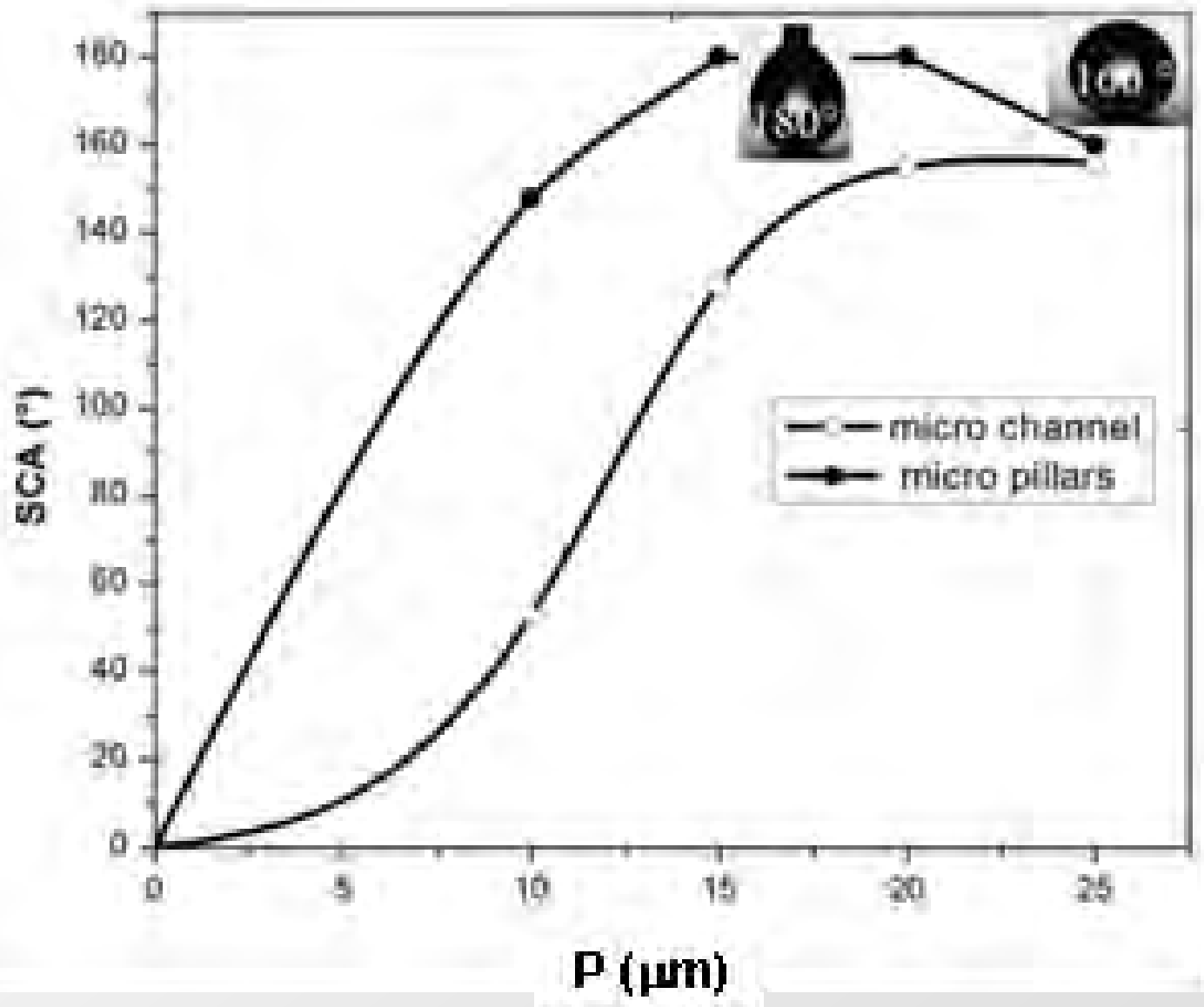

$\varnothing=15 \mu \mathrm{m}$

$\mathrm{F}=2,83 \mathrm{~J} / \mathrm{cm}^{2}$

$\mathrm{f}=100 \mathrm{kHz}$

$\mathrm{d}=10-25 \mu \mathrm{m}$

A: $d=10 \mu \mathrm{m}$

B: $d=15 \mu \mathrm{m}$

$C: d=20 \mu \mathrm{m}$

$D: d=25 \mu \mathrm{m}$ 


\section{$\mu$-Cells: The Key Feature for High Degree of Hydrophobicity}

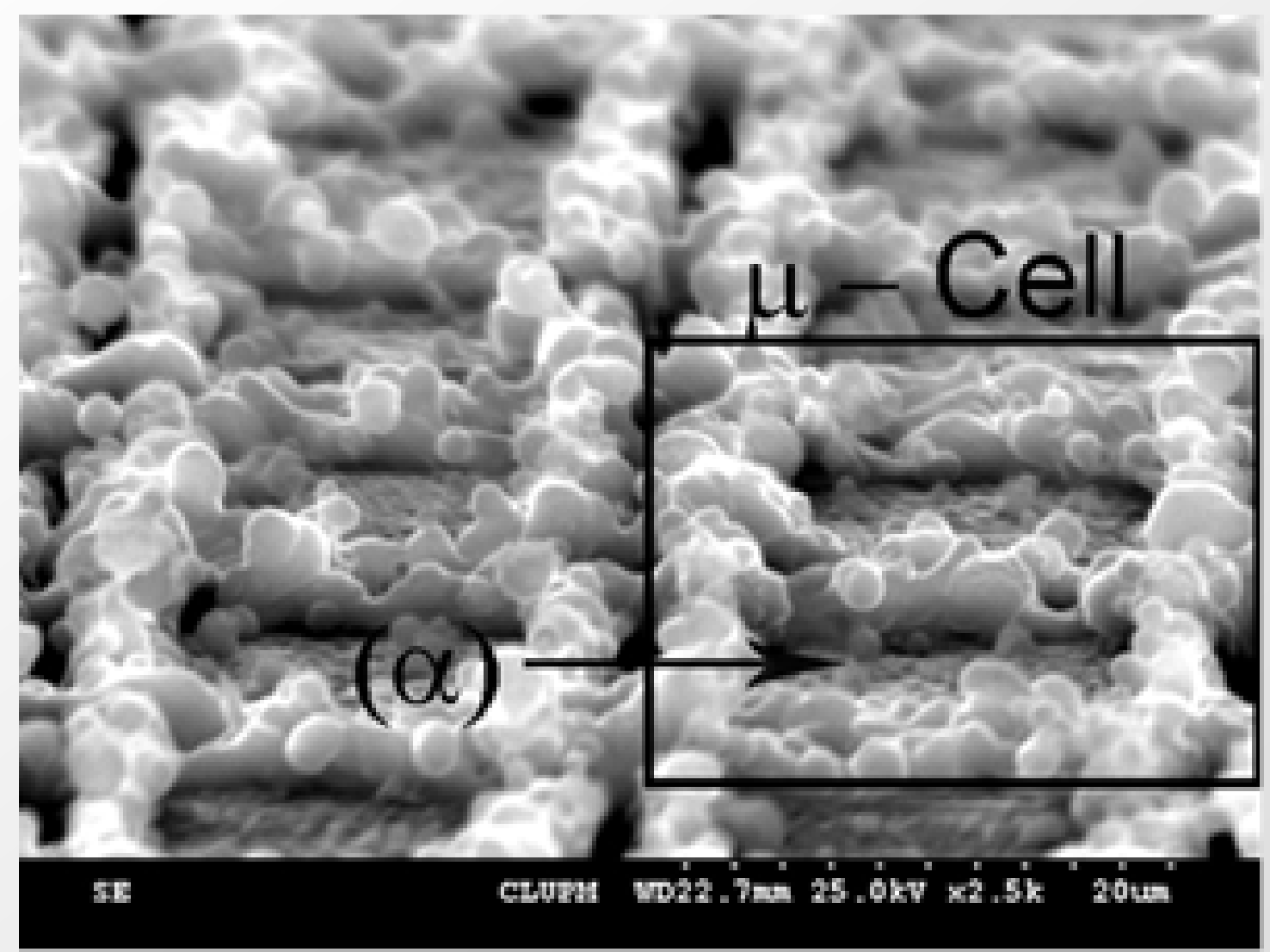




\section{RESULTS (III)}

\section{$\mu$-Cells: The Key Feature for High Degree of Hydrophobicity}
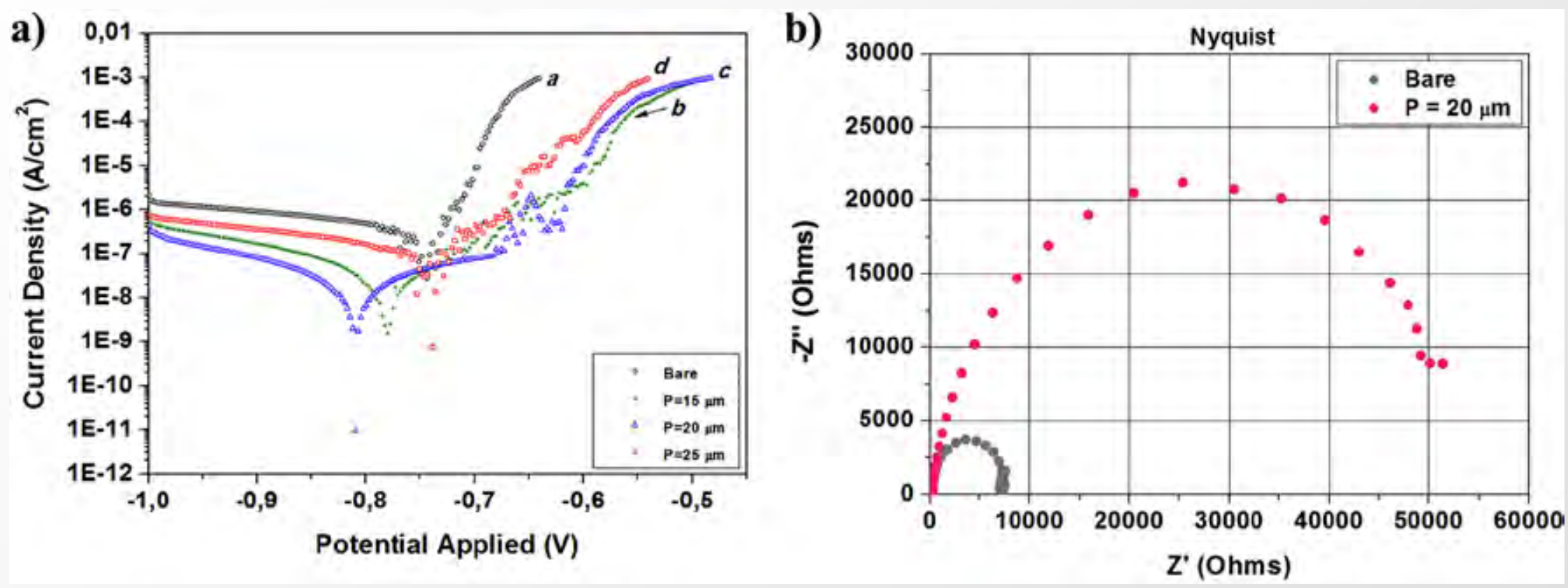

Table 1

Open circuit potential measurements and SCA.

Table 2

Parameters extracted from cyclic polarization curves.

\begin{tabular}{lll}
\hline & OCP $(V)$ & Contact angle $\left(^{\circ}\right)$ \\
\hline Bare aluminum & -0.754 & $85 \pm 3$ \\
$\mathrm{P}=15 \mu \mathrm{m}$ & -0.704 & 168 \\
$\mathrm{P}=20 \mu \mathrm{m}$ & -0.695 & 180 \\
$\mathrm{P}=25 \mu \mathrm{m}$ & -0.704 & 160 \\
\hline
\end{tabular}

\begin{tabular}{|c|c|c|c|}
\hline & $\mathrm{E}_{\text {carr }}(V)$ & $\mathrm{I}_{\mathrm{car}}\left(\mathrm{nA} \mathrm{cm} \mathrm{cm}^{-2}\right)$ & Corrosion rate $(\mu \mathrm{m} /$ year $)$ \\
\hline Bare Aluminum & -0.753 & 215.3 & 1.867 \\
\hline $15 \mathrm{HD}$ & -0.781 & 14.4 & 0.166 \\
\hline $20 \mathrm{HD}$ & -0.810 & 11,3 & 0.124 \\
\hline $25 \mathrm{HD}$ & -0.747 & 82.4 & 0.918 \\
\hline
\end{tabular}

L. Ruiz de Lara et al.: Materials Letters, 184 (2016), 100-103.

\section{CENTRO LÁSER}

UNIVERSIDAD POLITECAICA DE MADRIO

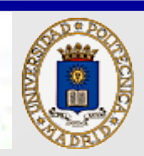

10. INTERNATIONAL LASER SYMPOSIUM \& INTERNATIONAL SYMPOSIUM

"TAILORED JOINING. 


\section{DISCUSSION: THE WAY FOR LOW WETTABILITY SURFACES}
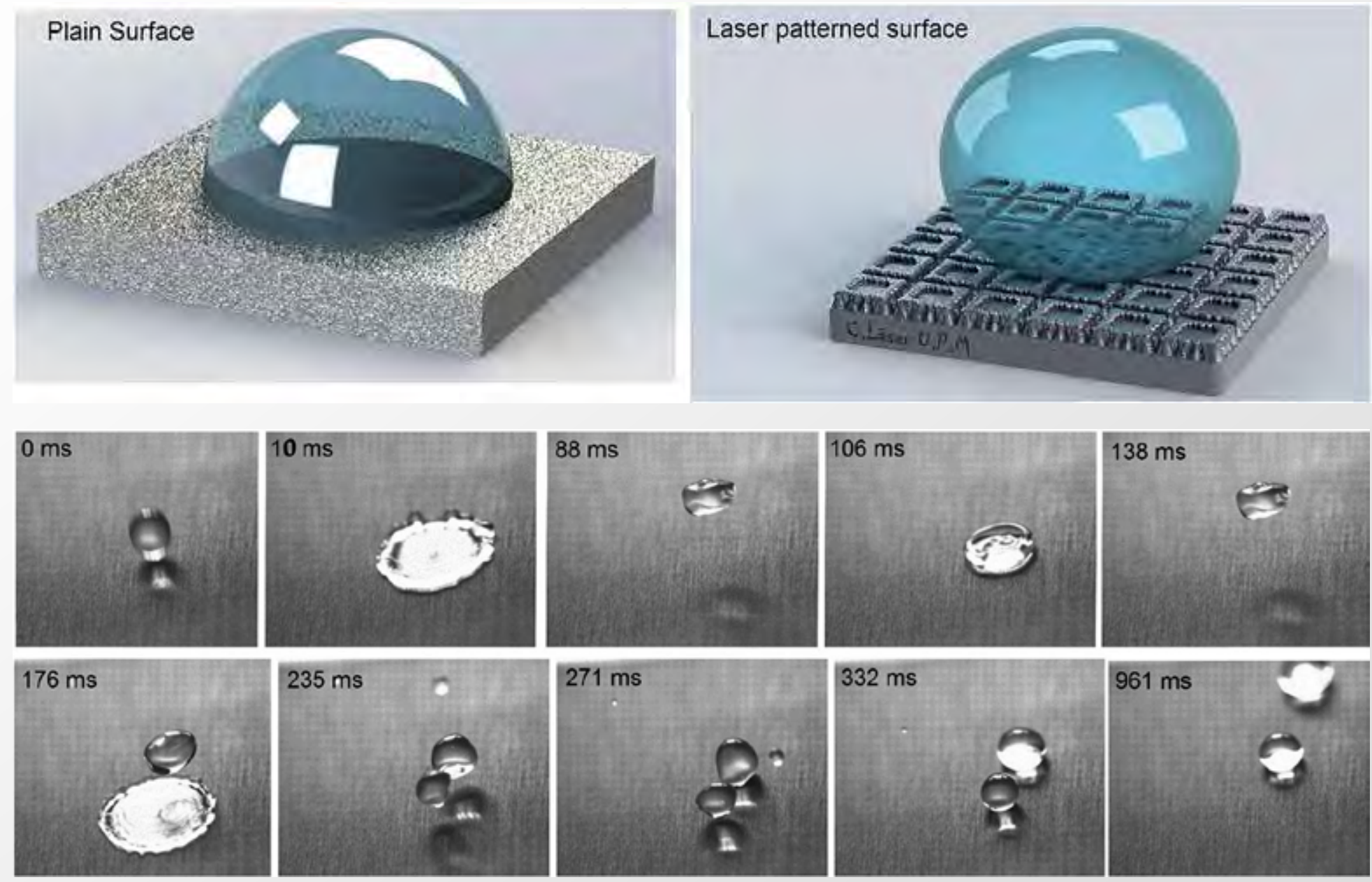

R. Jagdheesh et al.: J. Mater. Chem. A, 5 (2017), 7125-7136. 


\section{DISCUSSION: THE WAY FOR LOW WETTABILITY SURFACES}

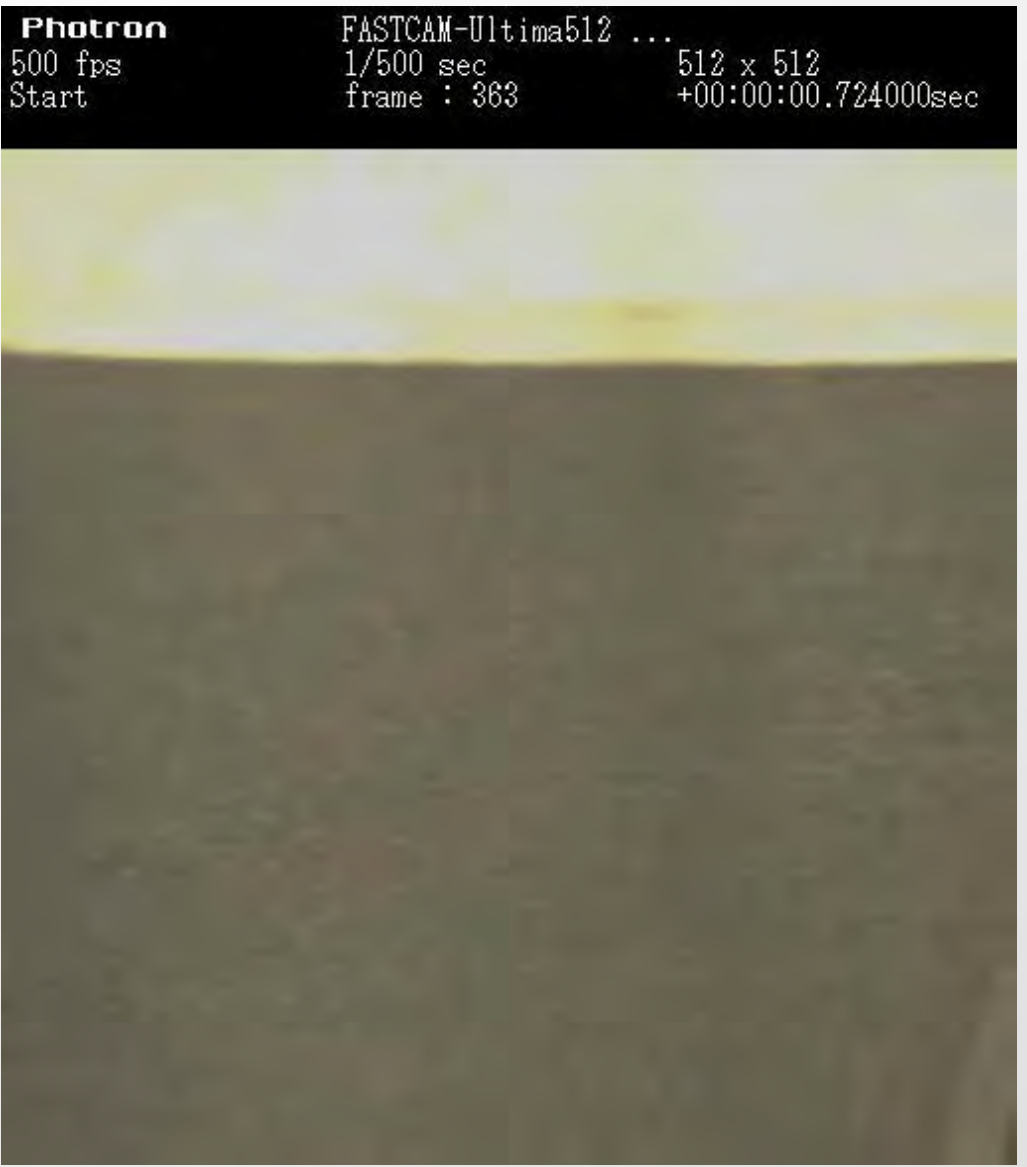

R. Jagdheesh et al.: J. Mater. Chem. A, 5 (2017), 7125-7136. 


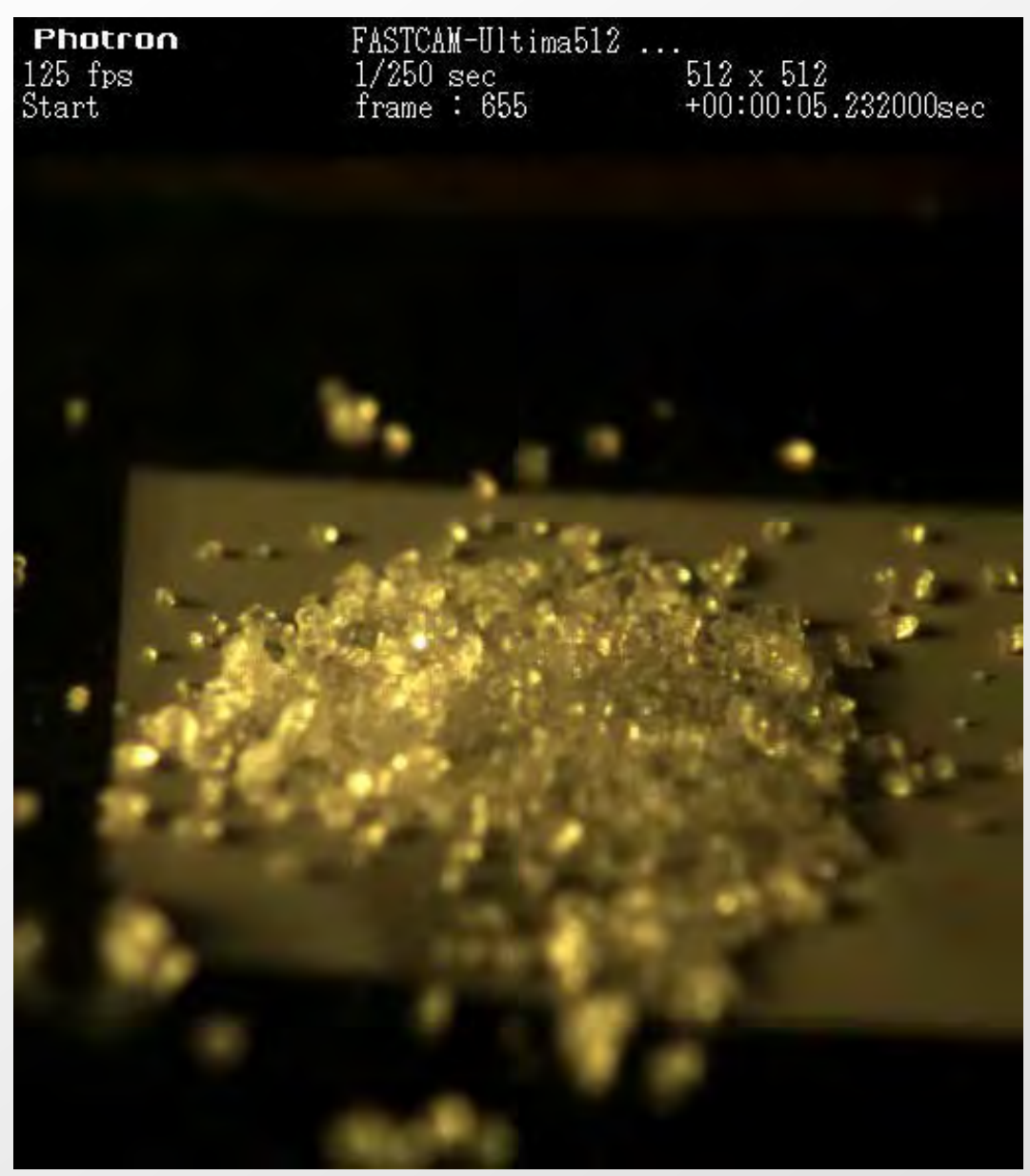

R. Jagdheesh et al.: RSC Adv., $\underline{6}$ (2016), 72933-72941 


\section{FINAL CONCLUSIONS}

- The application of nanosecond laser pulses on flat surfaces of aluminium (Al) in a one-step process leading to the generation of extended areas of stable superhydrophobic behaviour has been reported.

- Both laser generated periodic structures consisting in laser channels and laser pillars have been successfully developed with the aid of a $30 \mathrm{~ns}$ pulse, $100 \mathrm{kHz}$ repetition rate and $300 \mathrm{~mW}$ average power laser emitting at $\lambda=355 \mathrm{~nm}$ working at selected focus diameter and scan speed for different hatch distance values. The resulting micropatterns were evaluated by scanning electron microscopy (SEM) and confocal laser scanning microscopy (CLSM) in order to make apparent the material/geometrical parameters of the generated structures and a direct measurement of static contact angle (SCA) was performed in order to evaluate the wettability of the generated surface.

- A conceptually relevant methodology has been defined for the systematic generation of hierarchical-like micro/nano-structures fulfilling the conditions for the generation of superhydrophobic surfaces through the generation of $\mu$-cells able to serve as air trapping structures responsible for a substantially inhibited wettability of the substrate.

- This development, in its road to industrial implementation, is now considered as the basis for the systematic single-step generation of large scale extended surfaces with adjusted wettability properties as required by the different kinds of self-cleaning applications. Undoubtedly, the demonstrated possibility of use of ns lasers with their present day industrial robustness and their amenability to processing workstations with high throughput properties will contribute to the industrial implementation of the described developments. 


\section{Work partly supported by Spanish Project MAT2012-37782, BSH Spain and H2020-MSCA-LASER4FUN}
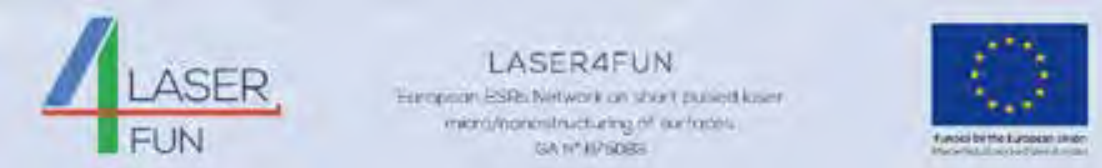

\section{MAIN REFERENCES}

[1] M. Miwa, A. Nakajima, A. Fujishima, K. Hashimoto, T. Watanabe: "Effects of the Surface Roughness on Sliding Angles of Water Droplets on Superhydrophobic Surfaces". Langmuir, 16 (2000) 5754-5760.

[2] X. Yao, Y. Song, L. Jiang: “Applications of Bio-Inspired Special Wettable Surfaces”. Adv. Mater., 23 (2011) $719-734$.

[3] T.L. Sun, G.Y. Qing: "Biomimetic Smart Interface Materials for Biological Application”, Adv. Mater., 23 (2011) H57H77.

[4] R. Jagdheesh, B. Pathiraj, E. Karatay, G.R.B.E. Romer, A.J. Huis in't Veld: "Laser-Induced Nanoscale Superhydrophobic Structures on Metal Surfaces". Langmuir, 27 (2011) 8464-8469.

[5] R. Jagdheesh: "Fabrication of a Superhydrophobic Al2O3 Surface Using Picosecond Laser Pulses". Langmuir, 30 (2014) 12067-12073.

[6] R. Jagdheesh, J.J. García-Ballesteros, J.L. Ocaña: "One-Step fabrication of near Superhydrophobic Aluminum Surface by Nanosecond Laser Ablation". Applied Surface Science, 374 (2016), 2-11.

[7] J.L. Ocaña, R. Jagdheesh, J.J. García-Ballesteros: “Direct Generation of Superhydrophobic Microstructures in Metals by UV Laser Sources in the Nanosecond Regime". Applied Optical Technologies, $\underline{5}$ (2016), $87-93$.

[8] R. Jagdheesh, M. Diaz, J. L. Ocaña: "Bio-inspired Self-cleaning Ultrahydrophobic Aluminium Surface by Laser Processing". RSC Adv., 6 (2016), 72933-72941.

[9] R. Jagdheesh, M. Diaz, S. Marimuthu, J.L. Ocaña: "Robust fabrication of $m$-patterns with tunable and durable wetting properties: hydrophilic to ultrahydrophobic via a vacuum process". J. Mater. Chem. A, 5 (2017), 71257136.

[10] L. Ruiz de Lara, R. Jagdheesh, J.L. Ocaña: “Corrosion Resistance of Laser Patterned Ultrahydrophobic Aluminium Surface”. Materials Letters, 184 (2016), 100-103. 
Thane you were y mulch for your attention! 


\section{MICROMANUFACTURING EXPERIMENTAL SETUP AT CLUPM}
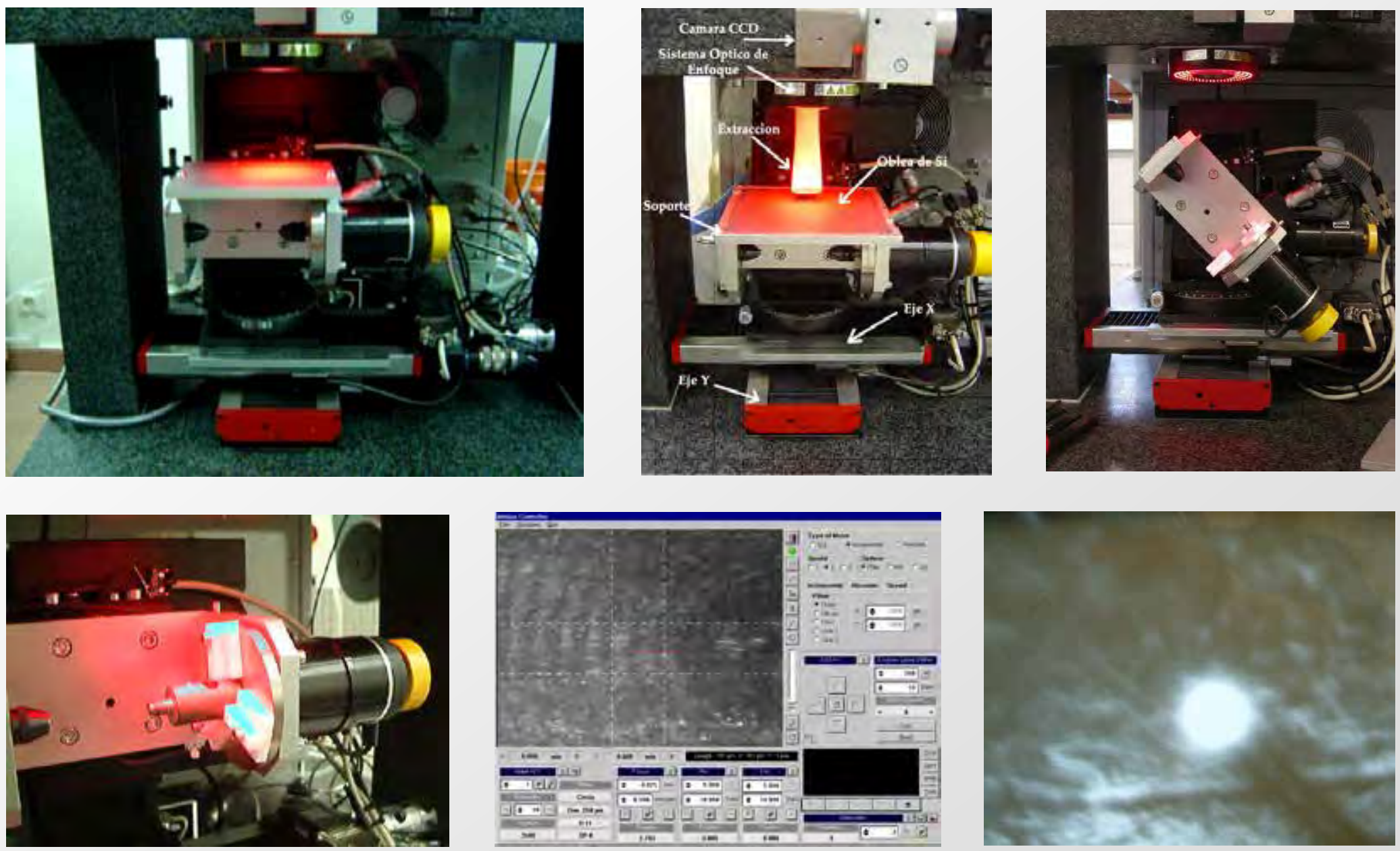

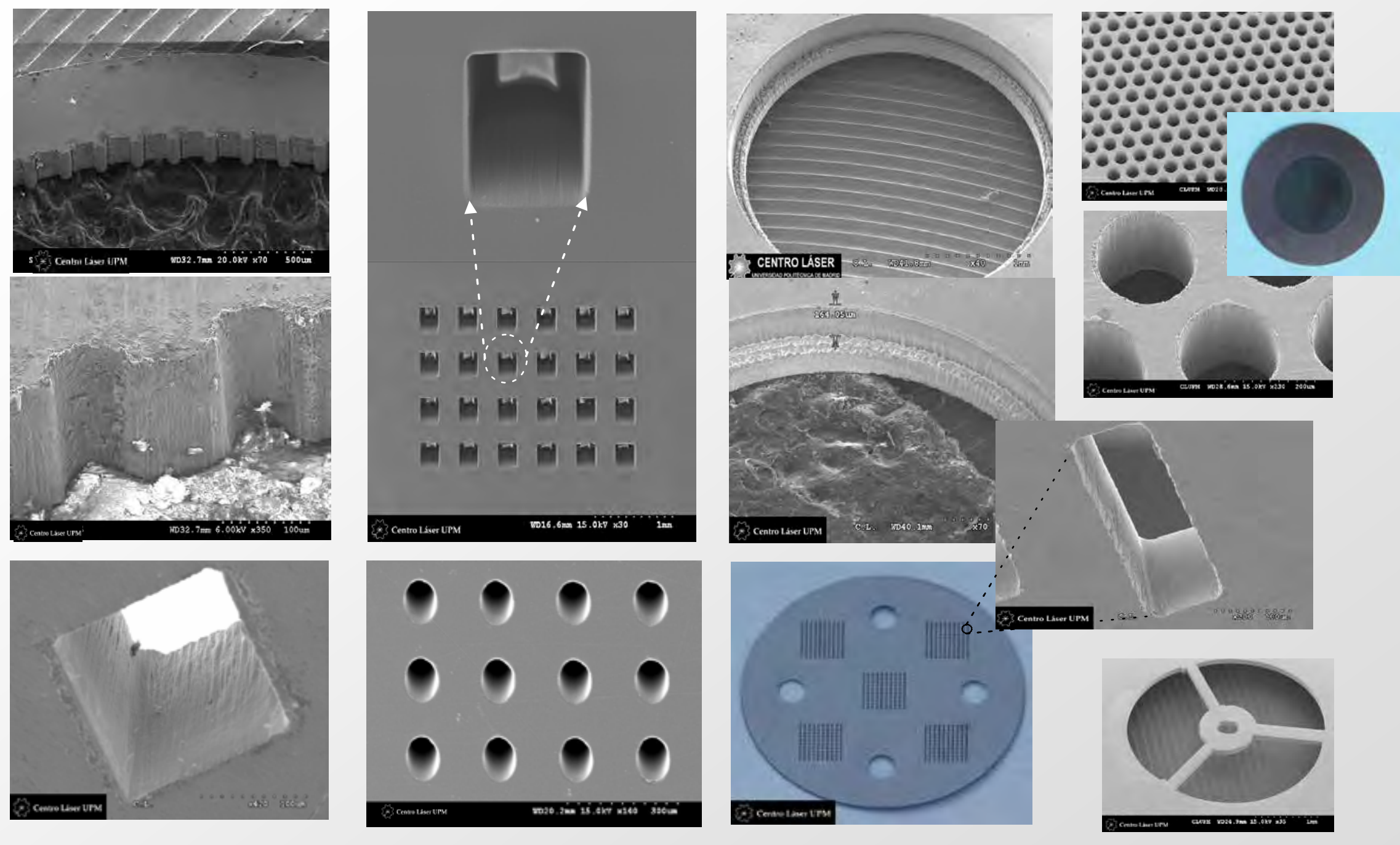

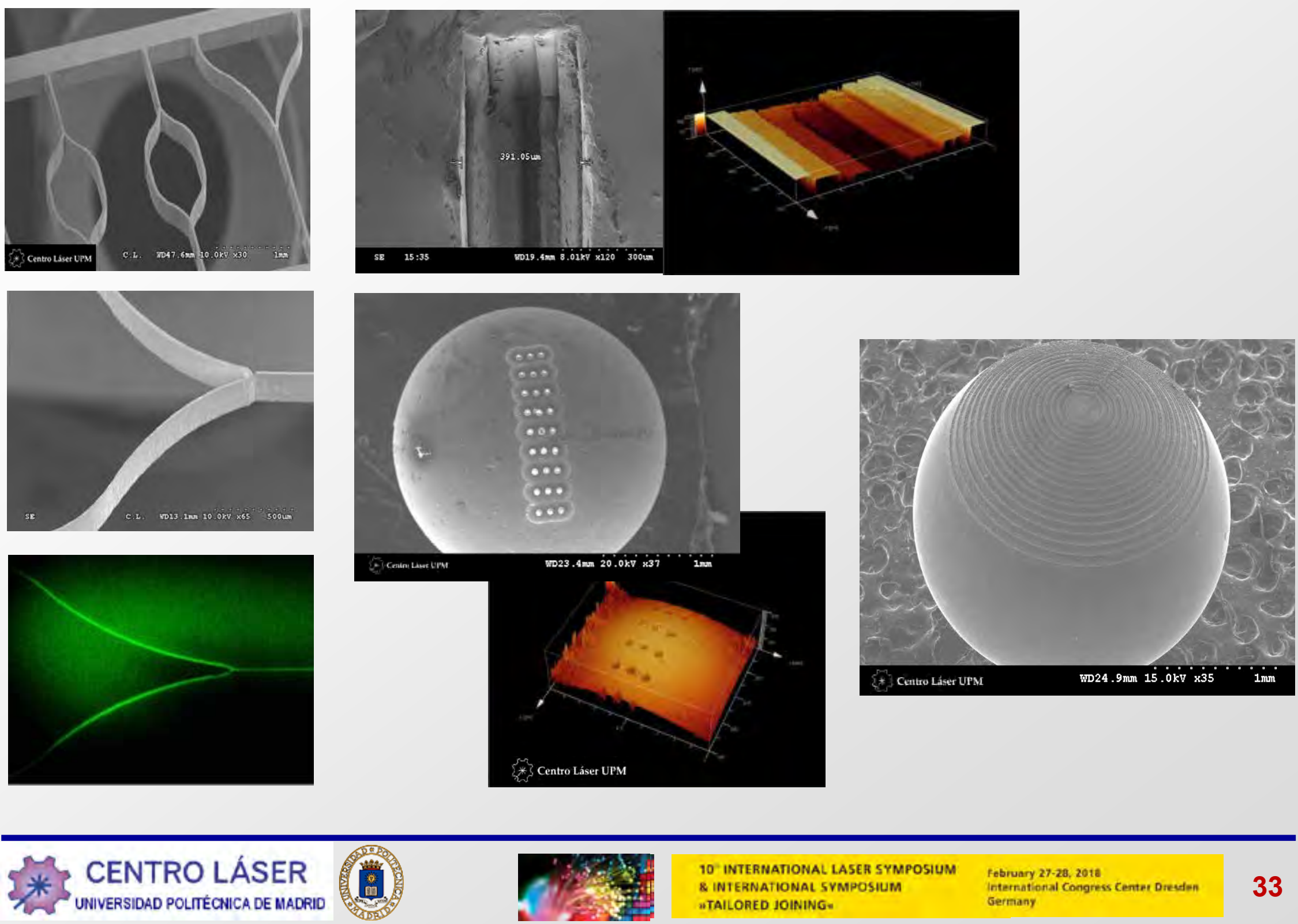

10. INTERNATIONAL LASER SYMPOSIUM $\&$ INTERNATIONAL SYMPOSIUM "TAILORED IOINING.
February 27-28, 2010 Iternational Congress Centre Dieuden Germiany 

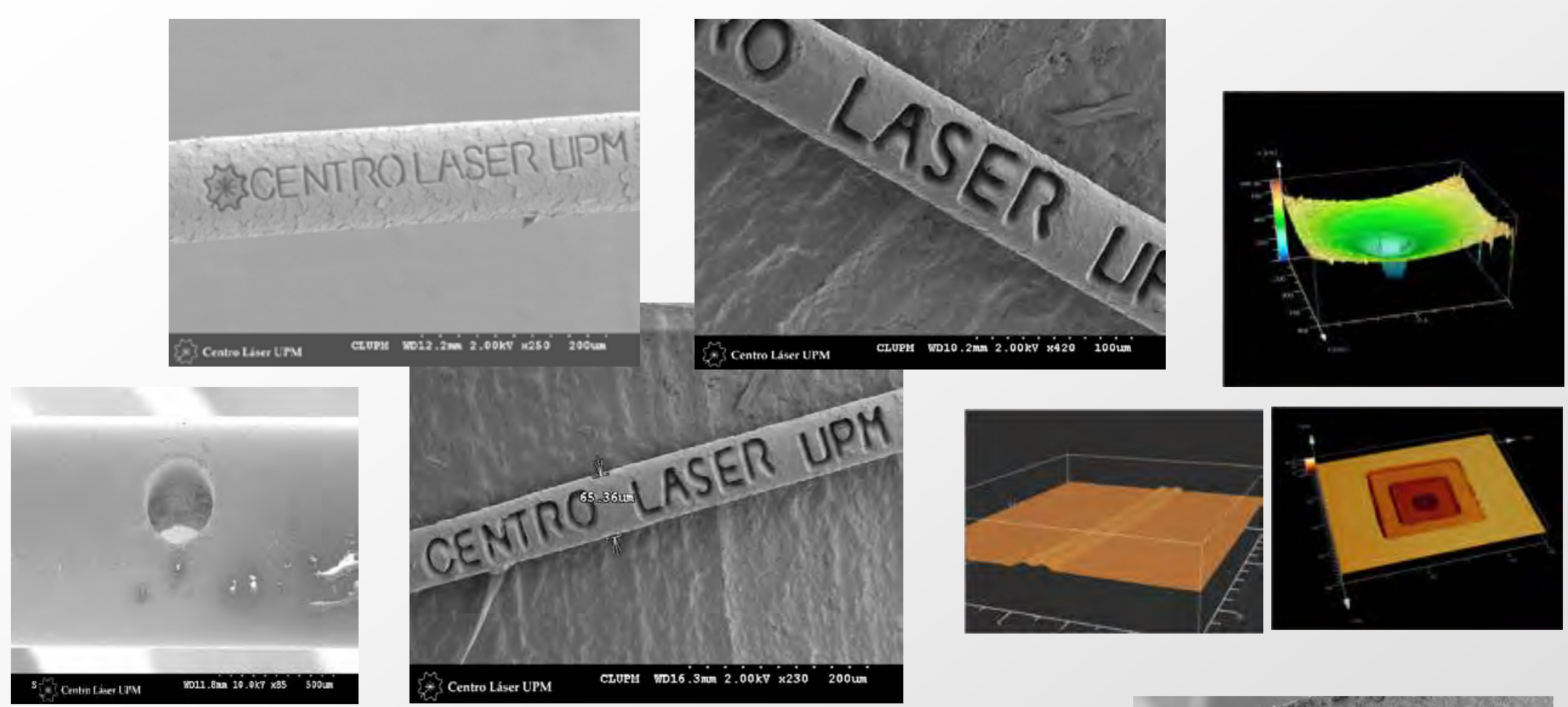

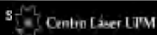

nol1. $\sin 10.0 \times 7 \times 655$ 5000
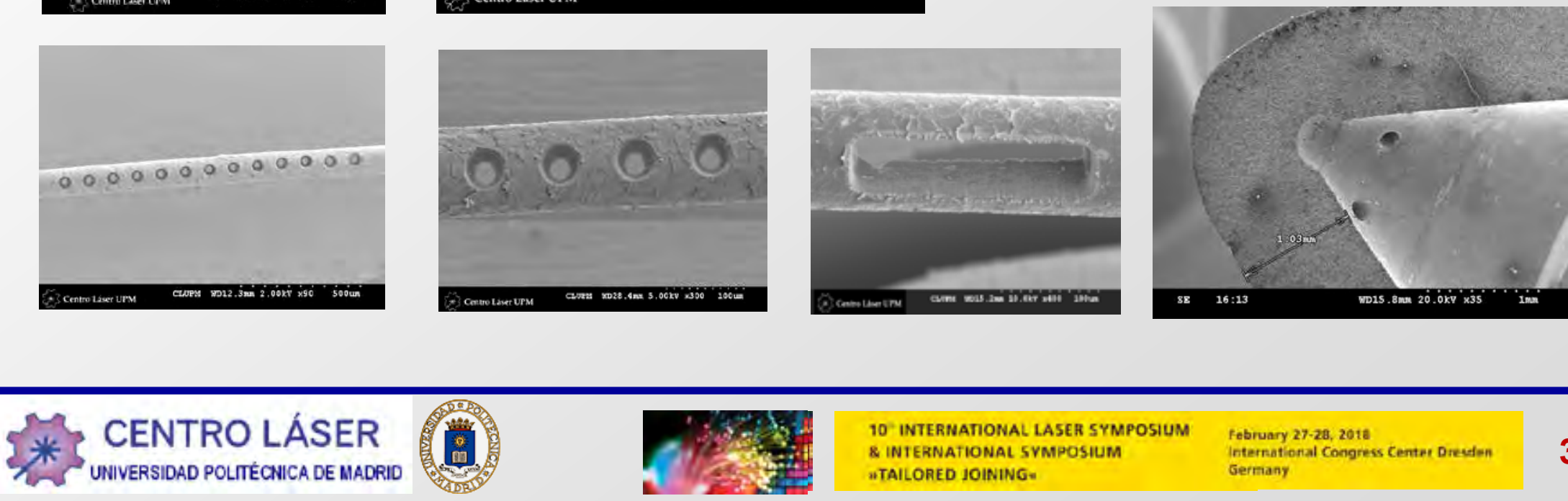

10. INTERNATIONAL LASER SYMPOSIUM $\&$ INTERNATIONAL SYMPOSIUM

"TAILORED JOINING.
Pebruary 27-28, 2010 international Congress Centre Dieuten Germiany 

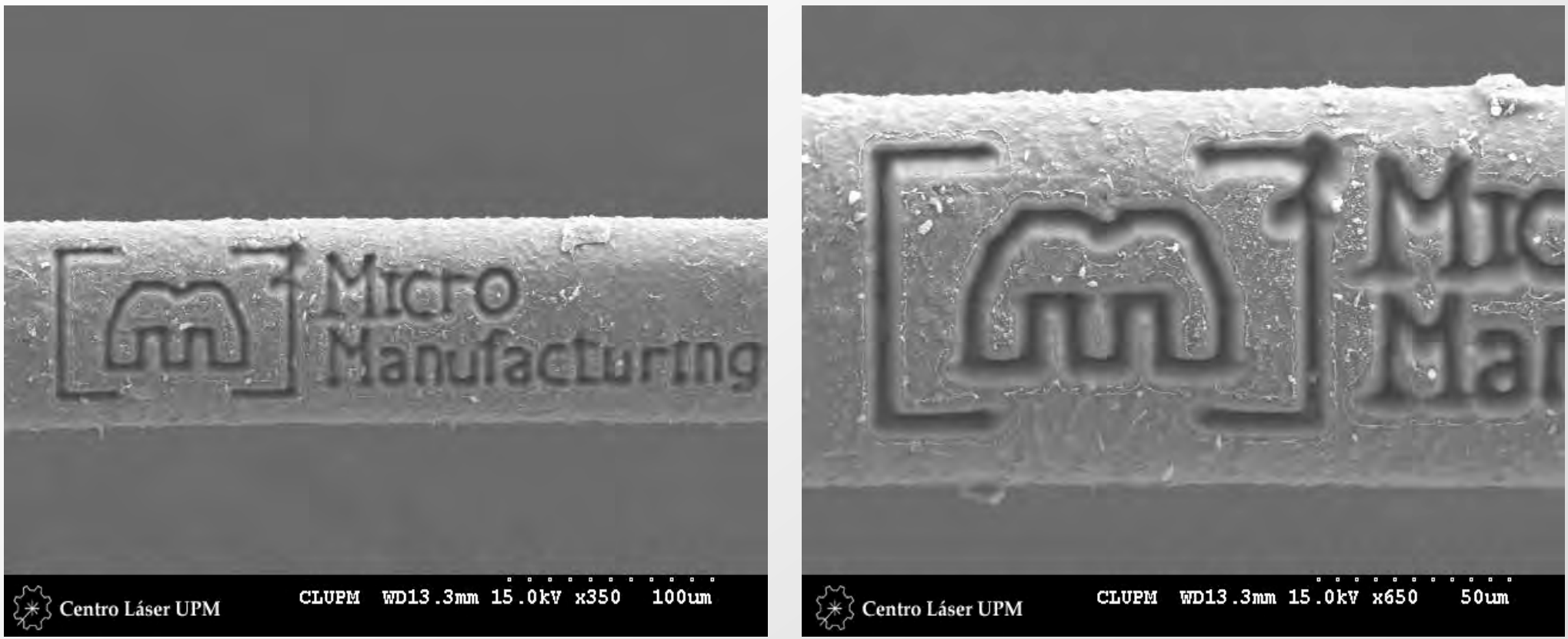